\title{
Trends of Radicalization among the Ranks of the Afghan National Police
}

A Research and Policy Paper

Robert Zaman | Abdul Hadi Khalid

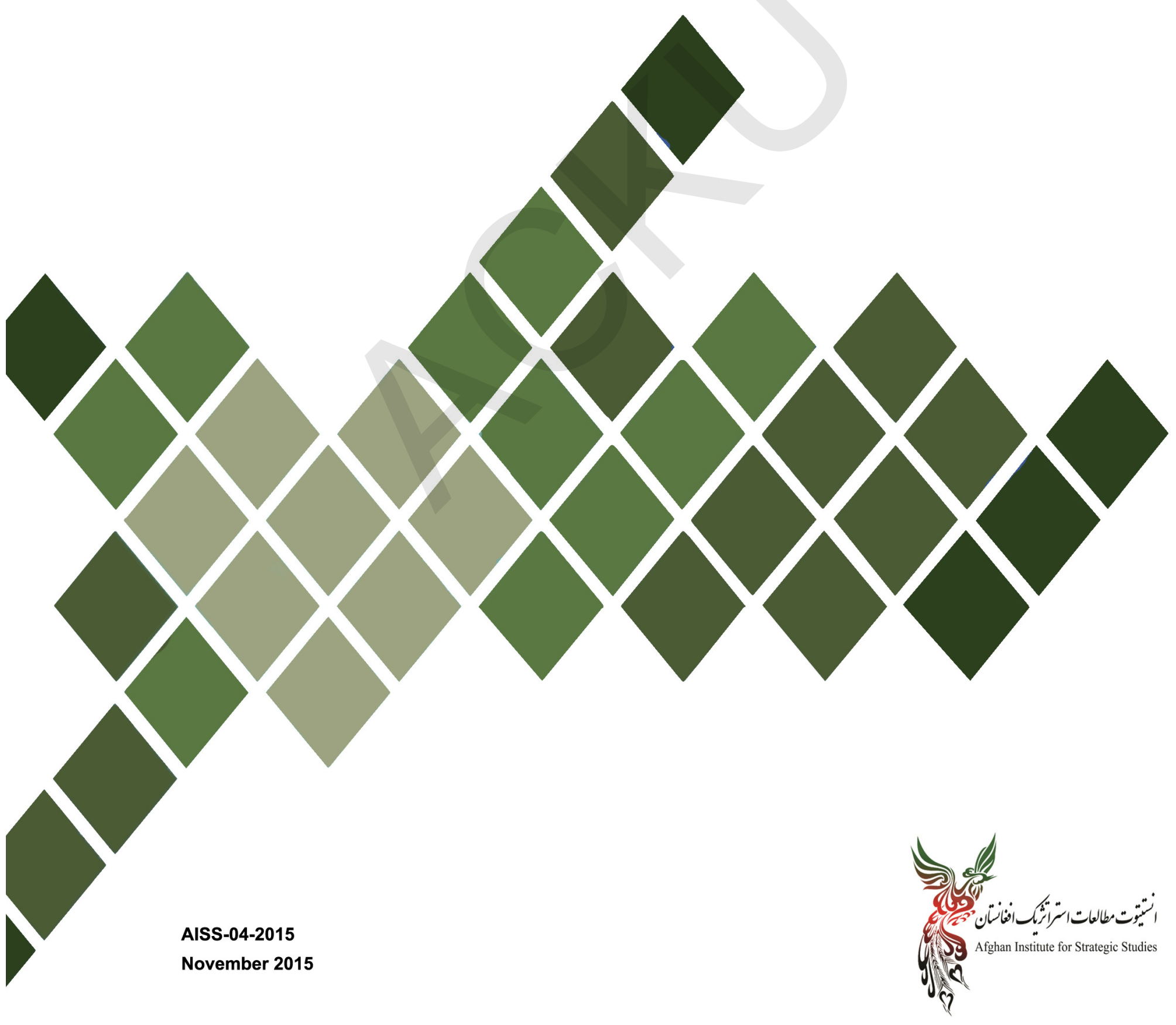


This Page Intentionally Left Blank

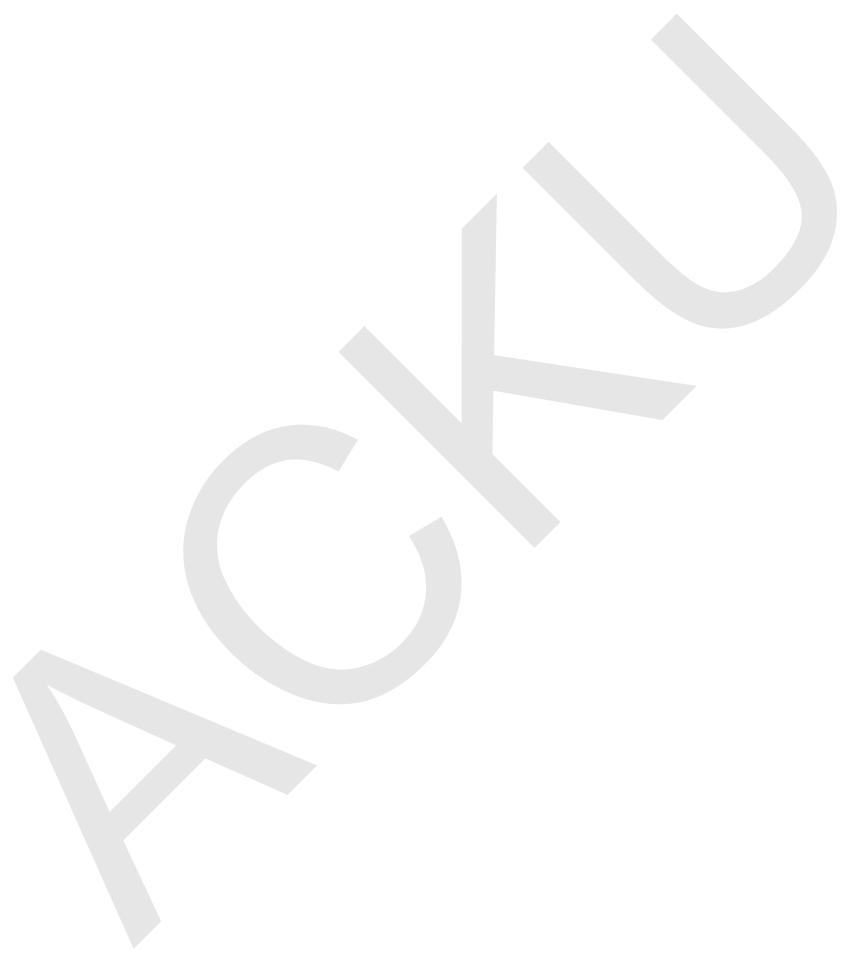




\section{Trends of Radicalization among the Ranks of the Afghan National Police}

Authors: Mr. Robert Zaman, General Abdul Hadi Khalid

Project Coordinator: Mr. Musab Omer

Principal Researchers: Mr. Abdul Ahad Mohammadi, Ms. Mariam Hotaki, and Mr. Musab Omer

Research Design Review and Peer Review

- Professor Shahrbanou Tadjbakhsh, Director of the program on Human Security at the Master of Public Affairs (MPA), Institute of Political Studies, Sciences Po, Paris and Associate Researcher, Peace Research Institute of Oslo (PRIO)

- Ms. Vanda Felbab-Brown, Senior Fellow in the Center for 21st Century Security and Intelligence in the Foreign Policy program, Brookings Institution, USA

Field Research Coordinator: Ghulam Reza Ebrahimi

Field Researchers

Hassan Jafari

Jafar Hosainzada

Mohammad Qadamshah

Bashir Ahmad Osmani

Fazel Ahmad Obaid

Abdul Basir Moheb

Essa Mohammad Zaheer

Muhammad Yaqoob Salih

Hussain Kazemian

Abdullah Tawakkoli

Mohammad Zahir Sarhadi
Aghashirin Shekohmand

Dour Mohammad Khan

Ihsanullah Hamidi

Matiullah Mohammad Aslam Khan

Khalid Yousafzai

Khalil Rahman Noori

Mohammad Rasool Zahiri

Abdul Samad Amiri

Nasrullah Ghori

Abdul Qadeer Wafa

Jawad Soltani 
This Page Intentionally Left Blank

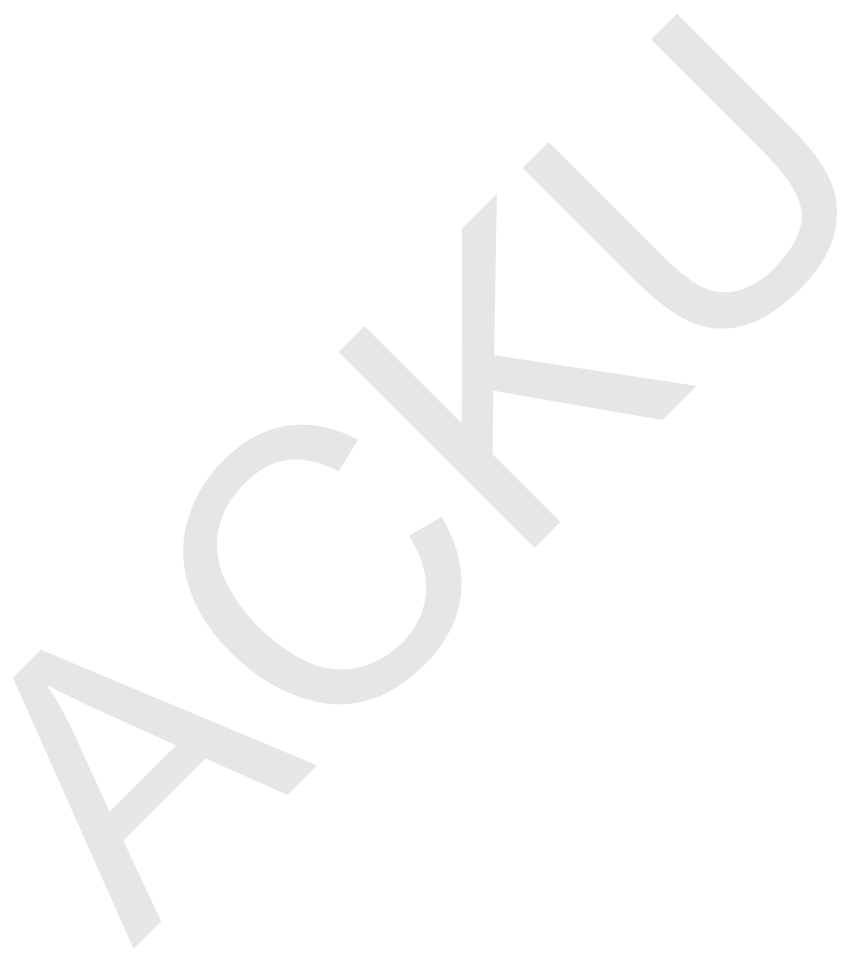




\section{CONTENTS}

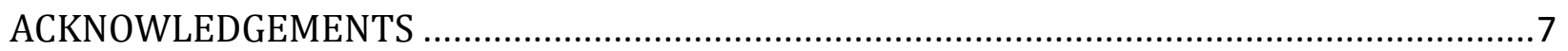

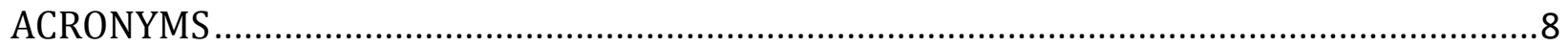

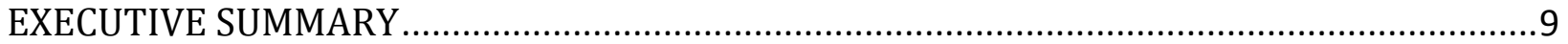

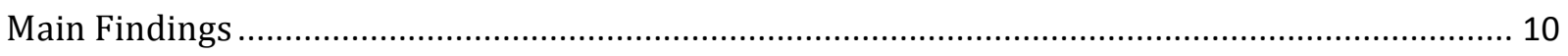

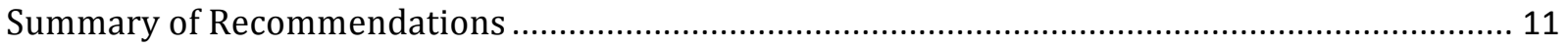

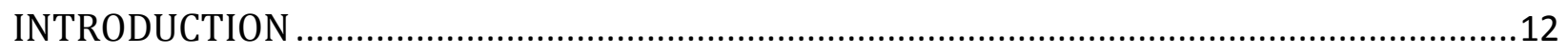

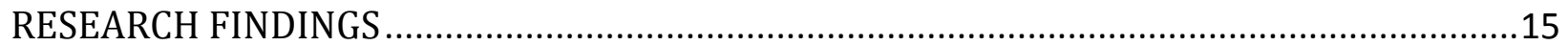

On Politic Deviance: Democracy, International Partnership, and (Revived) Taliban Governance......... 15

Views on Leadership and the Practice of Democratic Governance in Afghanistan ......................... 15

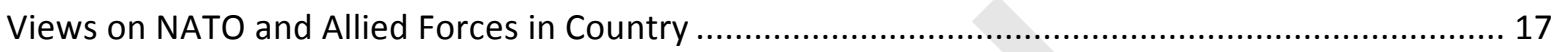

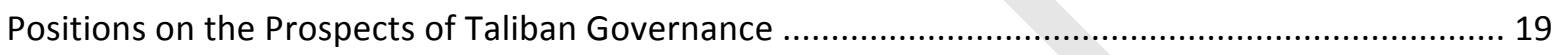

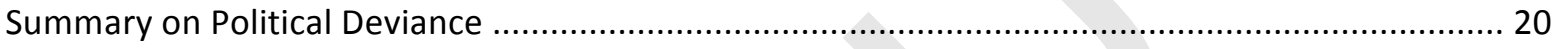

On Religious Extremism: Religious Beliefs and Interpretation, Tolerance, and Compatibility with

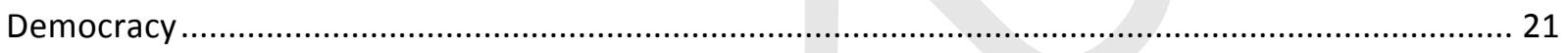

Religious Interpretations and Beliefs among Security Forces Personnel....................................... 21

Religious Tolerance and Inter-Ethnic and Sectarian Fraternity ................................................... 22

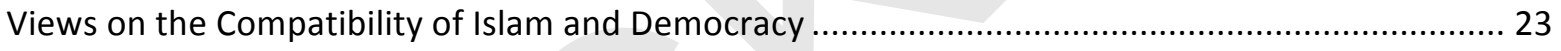

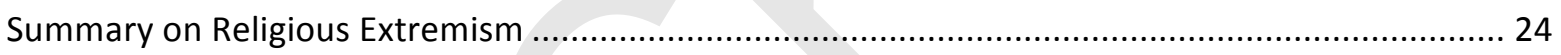

On Social Intolerance: International Norms and Values, Women and Human Rights, and Afghan

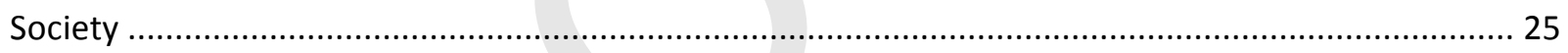

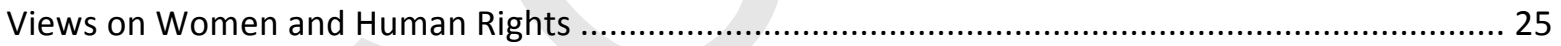

Views on the Compatibility of International Norms and Values and Islam .................................... 26

Views on the Compatibility of International Norms and Values within Afghan Society................... 27

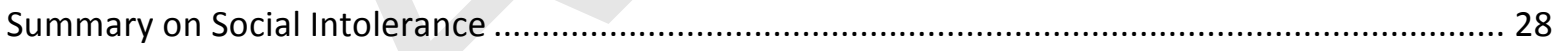

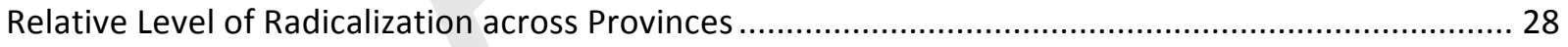

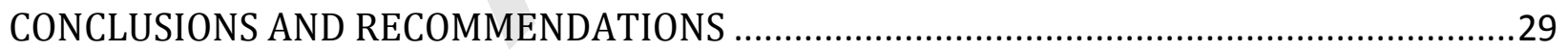

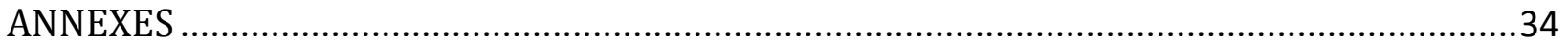

Annex 1: Statistics on the Afghan National Security and Defense Force ....................................... 34

Annex 2: Research Design and Methodology ............................................................................ 36

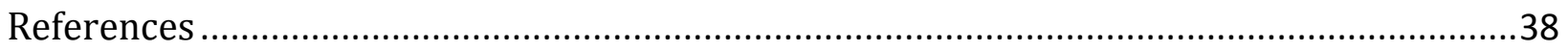

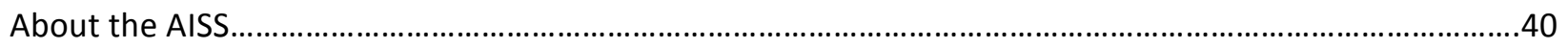

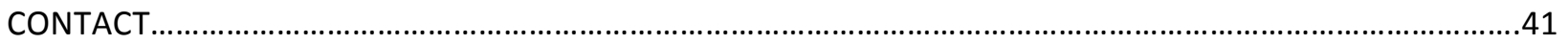




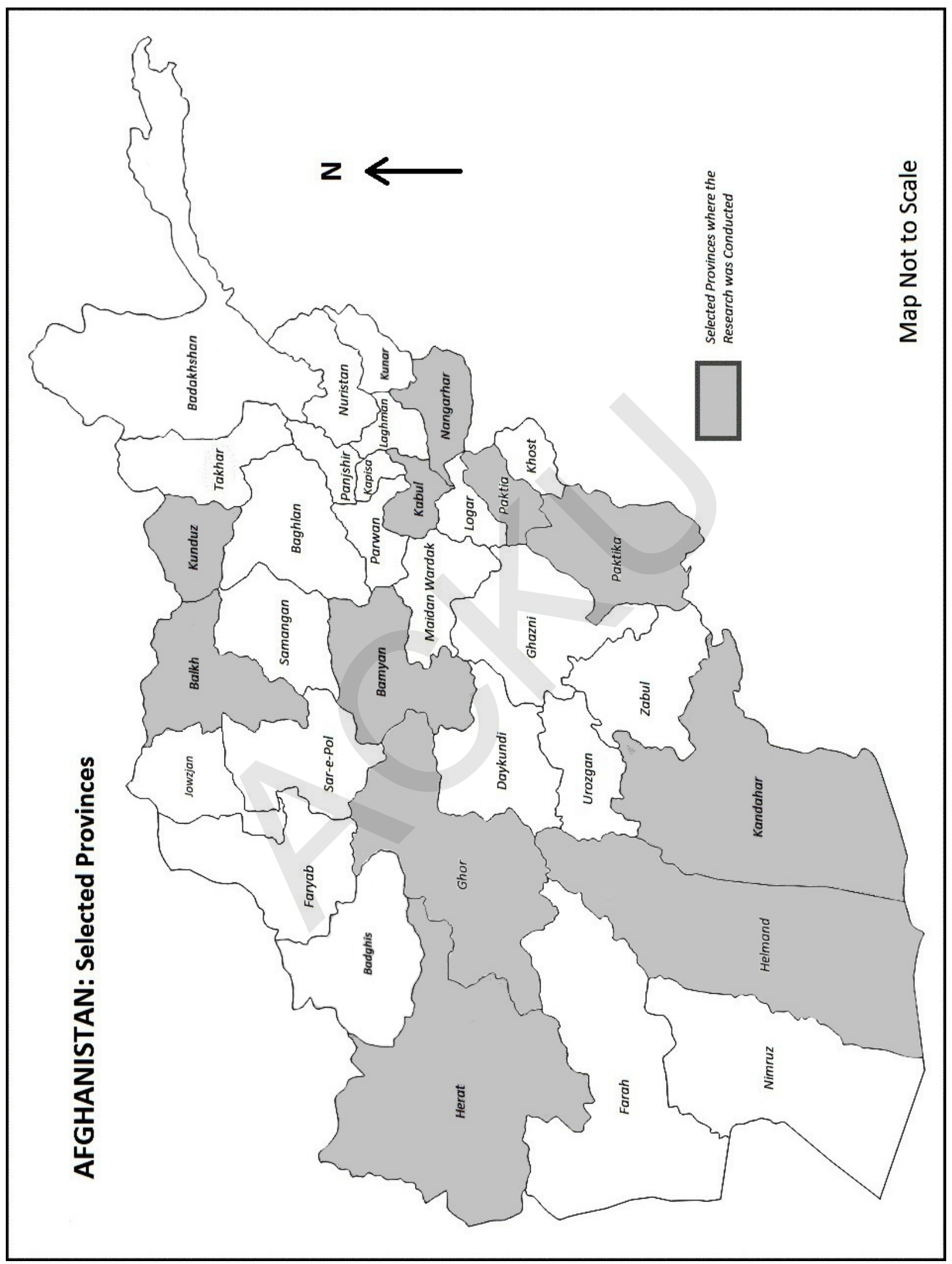




\section{ACKNOWLEDGEMENTS}

The authors are grateful to the Afghan Institute for Strategic Studies (AISS) for its logistical support and to the United States Institute for Peace (USIP) for its generous financial contribution to this project.

We are also grateful to our chief academic advisor, Professor Shahrbanou Tadjbakhsh, for her very thoughtful comments and suggestions throughout the development of this report. We also owe a particularly special thanks to our field researchers for their patience and tireless contribution in the field, to our principal researchers, Ms. Mariam Hotaki and Mr. Musab Omer, for their critical review and oversight of the entire project, and to Mr. Abdul Ahad Mohammadi and Mr. Husain Ali Karimi for their uncompromising dedication to delivering a robust data set for analysis. 


\section{ACRONYMS}

AACP Afghan Anti-Crime Police

AAF Afghan Air Force

ABP Afghan Border Patrol

AISS Afghan Institute for Strategic Studies

ALP Afghan Local Police

ANA Afghan National Army

ANCOP Afghan National Civil Order Police

ANDSF Afghan National Defense and Security Force

ANP Afghan National Police

ANSF Afghan National Security Force

APPF Afghan Public Protection Force

ASNF Afghan Special Narcotics Force

AUP Afghan Uniformed Police

CM Capability Milestone

ISAF International Security Assistance Force

NATO North Atlantic Treaty Organization

PD Political Deviance

RE Religious Extremism

SI Social Intolerance

USIP United States Institute of Peace 


\section{EXECUTIVE SUMMARY}

This study examines and compares trends of radicalization among the ranks of Afghan National Police (ANP) force across eleven provinces in Afghanistan. This is the first part of an ongoing series of papers dedicated to examining the evolving trends in radicalization among the Afghan National Defense and Security Force (ANDSF). Since the formation of the defense and security in 2002, various potential manifestations of radicalization, including insider attacks, dereliction of duty, and desertion have plagued its ranks. Radicalization is broadly defined as constraints on both the perspective of individuals and their tolerance to ideology and practices which diverge and differentiate from their own political, religious and social beliefs. Making the distinction between political deviance (PD), religious extremism (RE), and social intolerance (SI), 1498 uniformed rank and file personnel, 151 commissioned officers, and 8 uniformed religious leaders from among the ANP were surveyed on their views toward the political system in Afghanistan, anti-government elements including the Taliban, democracy in light of Islamic values, and women and human rights.

This study advances three overarching conclusions. First, although most security personnel increasingly over the course of their career accept centralized democratic governance, conservative views leaning toward extremist ideology persists among the ranks of security force personnel in some provinces, namely Qandahar. Second, reliance on local leaders from Qandahar and similarly conservative provinces for recruit recommendations encourages parallel and competitive loyalties and ideologies grounded on nepotism and patronage relations among the ranks. Finally, while grievances and animosities incited by favoritism and nepotism have led to the relative discredit of political and military leadership among security personnel, an overwhelming number of respondents continue to find the office of the President as a legitimate source of authority, suggesting that the alleviation of corruption is a first step toward building confidence and support of centralized democratic governance in Afghanistan.

Security and defense forces are the means by which governments enforce law and maintain its monopoly on their legitimate use of force. Failure of the Afghan government to develop confidence and loyalty among its security and defense personnel to the moderate ideology of the center not only runs the risk of finding itself both ideologically and physically in opposition to its own well-trained security and defense personnel, it more broadly challenges its domestic sovereignty. As a means for confronting such contest of its ideological legitimacy among the ranks of the ANP, military and political leadership must take ownership of the vetting, recruiting, training, and oversight of personnel rather than tolerating largely autonomous and parallel structures of authority to circumvent its law enforcement obligations and monopoly on the legitimate use of force. Failure to address such concerns is likely to be met with a return to a fragmentation state wherein largely autonomous and parallel governance structures may co-opt security force personnel as a means for enforcing their own counter, and potentially radicalized, ideology. 


\section{Main Findings}

Political deviance is an indication and measurement of dissatisfaction and resistance toward largely accepted political order and an ambition to establish alternative governance structures. Political deviance includes assessments of confidence in the current governance structure and views on its legitimacy.

- More than $68 \%$ of those polled believe that corruption exists among the ranks of the security force and its political and military leadership, while more than $72 \%$ believe that armed resistance by the people is justified against those found to be corrupt, despite the presence and jurisdiction of security and defense personnel.

- While approximately $11 \%$ of service members joined the security force with the aim of securing Afghanistan against Taliban influence, nearly $20 \%$ joined primarily for economic incentives. As a consequence, many maintain a hired hand mentality rather than national consciousness.

- A majority of green-on-blue incidents were of a personal and intimate nature rather than collective action, suggesting that individual grievances, personal mental states, and ideological beliefs were the underlying motivations.

Religious extremism is characterized by deviations from accepted moderate religious views and practices and a turn toward more extreme interpretations of religious doctrine. Often the process is marked with a return to dated prescriptions of intolerance and discrimination and a call for violent resistance against perceived threats to the institution of outdated systems of order and legislation.

- Of those polled, $83 \%$ believe that armed resistance is justified against those who criticize Islam, while $76 \%$ of those from Paktia believing that the Taliban are good religious leaders, suggesting that religious ideological tension exists between the center and those in Paktia.

- More than $10 \%$ from both Paktia and Paktika believe that suicide attacks are a justified form of armed resistance.

- Relative to other provinces, those from Kunduz find more so that democracy is not compatible with Islam. These same respondents are also in favor of establishing a caliphate, suggesting that many from Kunduz believe in religious leadership without democracy.

Social intolerance measures the extent to which individuals are receptive to and appreciative of internationally accepted norms and values, believe that such standards are compatible with Afghan society, and agree that Afghans can be held accountable to such standards.

- Although this study finds that most are tolerant to ethnic and religious differences, increasingly over the course of their time-in-service nearly $25 \%$ believe that ethnic discrimination is a primary cause of conflict in Afghanistan.

- Nearly half of those polled believe that international conventions on women and human rights are not necessarily in line with Islamic values, with most of those coming from Kunduz and Qandahar. 
- More than $80 \%$ of those from Qandahar approve of physically reprimanding women for disobeying Islamic law or disrespecting Afghan tradition and culture.

\section{Summary of Recommendations}

The Ministry of Interior

- Should address concerns over corruption within the ranks of the ANP and among its military and political leadership as corruption is seen as justification for circumventing the authority of security and defense personnel and taking up arms against the leadership. Initiatives aimed at ending nepotism and other patronage links and the institution of oversight programs are first steps toward encouraging trust and reducing the likelihood of insurrection among the ranks of the ANP.

- Should revisit recruit and follow-on curriculum, specifically addressing the development of national consciousness and meeting misunderstandings over the compatibility of international norms and values and Afghan society and culture. Initiatives should standardize training programs which indoctrinate personnel on democratic values, government authority, and the role of its security and defense force to uphold the law and maintain a monopoly on the legitimate use of force.

- Should institute rotation tours of rank-and-file personnel and/or officers as a means of severing ties with local communities and the potential for ongoing ideological competition. Failure to divorce security personnel from ties with their local communities encourages tensions and competition between local ideologies, including Taliban and other influences, and that of the central democratic government.

- Should institute training on psychological operations and counter-influence techniques to meet with the influence and coercion tactics of local Taliban members.

The Ministry of Health

- Should oversee the development of initiatives aimed at initial and ongoing evaluations of the psychological health of service members. Personal grievances and animosities among members of the security force, ultimately provoke violence among its ranks, including against foreign forces, and potentially lead to defection or at least desertion.

Directorate of Religious Education and Training, the Ministry of Hajj and Religious Affairs

- Should institute programs under the management and direction of uniformed religious leaders which address concerns over the compatibility between Islamic values and internationally accepted norms and values. 


\section{INTRODUCTION}

Since the formation of the Afghan security and defense force in 2002, various potential manifestations of radicalization, including insider attacks, desertions, and dereliction of duty have plagued the ranks of the security force. Since 2008, green-on-blue incidents have largely demonstrated an upward trend mirroring an increasing ANDSF troop level with its peak in 2012 and gradual decline since then. On January 29, 2015 three US contractors were killed at Kabul International Airport when a service member of the Afghan National Army (ANA) opened fire on the group. The Taliban immediately claimed responsibility, pointing out that the soldier was a Taliban infiltrator ${ }^{1}$. In another incident on April 8, 2015, a member of the ANA opened fire on international forces who were escorting US diplomatic personnel across Jalalabad after attending a meeting with the provincial governor. Two were killed and another two were injured ${ }^{2}$. On September 15, 2014 four members of the International Security Assistance Forces (ISAF) were killed in two separate green on blue incidents ${ }^{3}$. In Kabul a suicide bomber detonated his device near the Supreme Court killing three ISAF members, while in Herat a member of the Afghan National Defense and Security Force (ANDSF) opened fire on international trainers, killing one of them.

Changes in desertion rates serve as an indication of shifts in service members' confidence in battle, perception of the righteousness of their role, and more generally popular support of the government. In 2002 , a lack of confidence was reflected in a near $50 \%$ desertion rate which slowly decreased over the course of the next few years as confidence increased ${ }^{4}$. However, with the US withdrawal of its forces from Afghanistan, desertion rate in 2014 increased again with up to $8.5 \%$ of ANA personnel failing to return to their posts ${ }^{5}$. In addition to such reasoning, the heaviest numbers of desertions are noted when members fail to return after a period of leave, suggesting that influences from their native local communities may also play a role in their decision to desert. Even more concerning are desertions where service members take weapons and vehicles as they switch sides to ally with anti-coalition forces $^{6}$. In combination, lack of confidence in defeating insurgents, questioning the righteousness of their role, and decreasing popular support for the government all play a role in influencing the decision to desert as well as the potential to become more receptive to counter and potentially radicalized ideology of opposition forces.

In addition to insider attacks and desertion, outright dereliction of duty are also reported among the ranks of the ANDSF. In particular, turning a blind eye ${ }^{7}$ to insurgent activities and carrying out unsanctioned cease fires between insurgents and service members were reported on a number of occasions $^{8}$. In fact, reportedly service members coexist in the very same local communities as insurgent members, passively allowing each other to go about their business.

With Milestone 2013, and more specifically Tranche 5 of the security transition, the final stages of the handover from ISAF to ANDSF concluded on January 1, 2015 leaving a small contingency of trainers and advisers from the NATO-led Resolute Support Mission (RSM) ${ }^{9}$. However, this continued support is not without its obstacles and apprehensions - namely that of meeting insider attackers and weeding out radical elements. 
The Afghan security and defense force has grown to a formidable number of approximately 328,805 strong with its personnel distributed across the army, air force, and police. As of June 29, 2015, the ANP stands at 155,182 with 95,389 allocated to its largest component, the Afghan Uniform Police (AUP) who is responsible for general policing duties including border control, counter-narcotics, traffic and fire, and counter-terrorism. The ANA is manned by approximately 167,024 , including 11,000 Special Forces personnel who function throughout Afghanistan at the direction of the President, while the Afghan Air Force (AAF) is staffed by approximately 7,000 personnel and has a fleet of 100 fixed-wing and rotary aircraft ${ }^{10}$. Of these numbers, only approximately 2,000 women fill the ranks of the ANDSF. According to the United States Department of Defense (DOD), this force of nearly half a million reaches more than $87 \%$ of the Afghan population ${ }^{11}$.

In response to insider attacks, desertions, and dereliction of duty, North Atlantic Treaty Organization (NATO) officials took steps to address concerns with the introduction of 'guardian angels' to watch over international forces in mixed company, improving the vetting process as part of a counter-infiltration plan, and increasing cultural awareness among the ranks of ISAF. In addition to monitoring and revetting personnel returning from leave or a period of absence, counter-intelligence and counterinfiltration staff now also embed among the ranks and monitor the behavior of personnel. All of which are good precautions which may limit the number of successful insider attacks, limit desertion rates, and discourage dereliction of duty, however such approach merely addresses the symptoms and fails to find and address the underlying causes.

The concept of radicalization has its origins in broad notions of tension and competition between existing ideology and competing parallel beliefs and behaviors which often take on a violent character of disruption, non-compliance, and inevitably a pursuit to depose existing order. Understood as a social movement of reform, the process remains in a near continuous state, with each successive experience and event reconditioning and reinforcing such beliefs and behavior. As a consequence, one would expect to find increasing levels of radicalization over time as the pressures and competition against one's beliefs increases. However, it is not the mere difference of belief and practices which constitutes radicalization, rather it is the taking of these differences as a means for alienation and violent resistance which qualifies as radicalized. For this study, three dimensions of the process of radicalization are considered: political deviance (PD), religious extremism (RE), and social intolerance (SI) and advance the following formula.

$$
\text { RADICALIZATION }=\text { PD }+ \text { RE }+ \text { SI }
$$

Political deviance (PD) as a component of the process of radicalization is an indication and measurement of dissatisfaction and resistance toward largely accepted political order and an ambition to establish alternative governance structures. Political deviance is marked by civil disobedience and potential acts of terrorism wherein individuals or groups "deliberately and intentionally violate laws and rules in order to call attention to what they perceive as being inherently unjust and oppressive"12. As a subject of examination aimed at identifying views and estimating individual acceptance of state leadership and 
governance, the concept of political deviance allows us to answer our first meta-question: to what extent do individuals accept the modernization and democratization of Afghanistan? In particular, political deviance include an assessment of confidence in the current governance structure, views on legitimacy, and individual participation in elections; whether democratic governance is compatible with Afghan society; and whether armed resistance is ever justified against the government.

Religious extremism (RE) on the other hand is characterized by deviations from accepted moderate religious views and practices and a turn toward more extreme interpretations of religious doctrine. Often the process is marked with a return to dated prescriptions of intolerance and discrimination and a call for violent resistance against perceived threats to the institution of outdated systems of order and legislation. Even amongst fellow believers, resistance may exist in the form of takfir, or the practice of excommunicating other Muslims who are perceived as having abandoned Islam ${ }^{13}$. As a means for gauging religious extremism, surveys aim to identify the extent to which individuals hold extreme interpretations of Islam, such as religious justification for violence, intolerance to non-Muslims, sectarian discrimination, and defiance of democratic principles.

Social intolerance (SI) measures the extent to which individuals are receptive to and appreciative of internationally accepted norms and values on women and human rights, and to what extent there exists the belief that Afghans are held accountable to such standards. Although international conventions on women and human rights are largely accepted as universal laws, at times they may compete with that which is domestically perceived as acceptable. For this study, we examine the views of security personnel on such universals principles and its compatibility with Afghan values and norms. In particular, views on internationally accepted norms and values and whether Afghans have a duty to adhere to these principle; views on women and human rights, including their role in society; and opinions on the compatibility of international norms and values with Afghan society are investigated.

The concept of radicalization is operationalized as the summation of the components of political deviance, religious extremism, and social intolerance, each of which provide indication and measurement of deviations from values, norms, and behaviors associated with democratic governance, moderate religious beliefs, and universally accepted norms and values.

Findings from this study are organized according to the factors of radicalization: political deviance (PD), religious extremism (RE), and social intolerance (SI), each of which take the following views, interpretations, and positions of members of the security force as units of measurements toward determining the extent of radicalization among the ANP.

Political Deviance:

- View on leadership and the practice of democratic governance in Afghanistan

- Views on NATO and allied forces in country

- Positions on the prospects of revived Taliban governance in Afghanistan 
Religious Extremism:

- Religious interpretations and beliefs among security force personnel

- Religious tolerance and inter-ethnic and sectarian fraternity

- Views on the compatibility of Islam and democracy

Social Intolerance:

- Views on women and human rights

- Views on internationally accepted norms and values and its compatibility with Islam

- Views on the compatibility of internationally accepted norms and values within Afghan society

\section{RESEARCH FINDINGS}

\section{On Politic Deviance: Democracy, International Partnership, and (Revived) Taliban Governance}

Participants were surveyed on their views of the leadership and practices of democratic governance in Afghanistan, their opinions on NATO and allied presence in the country, and their position on prospects of Taliban governance as a means for estimating political deviance and finding out evidence of radical ideology. In attempting to understand the nature and extent of their loyalties toward democratic governance in Afghanistan, this study works with the assumption that views which diverge from the norms and values established under the constitution demonstrates certain levels of controls on loyalty and commitment toward the central government and its rule. Where once respondents maintained allegiances either toward local traditional leadership or the Taliban government, since the 2001 invasion Afghans were offered a third option, that of allegiance toward centralized democratic governance. What is more, as members of the security and defense force, respondents are not only expected to stand ready to protect and defend the values established under the constitution, but also more broadly to enforce the legitimacy of this very same government.

\section{Views on Leadership and the Practice of Democratic Governance in Afghanistan}

Considering views on centralized democratic governance, more than half of those polled respect and find legitimate the office of the President (57.3\%) with more than three quarters (77.2\%) participating in elections. Although a relatively high number of respondents with less than one year of service from Kabul, Nangarhar, Qandahar, and Paktika did not participate in elections, increasingly with their time-inservice and from across all provinces respondents participated. In fact, when asked whether democratic governance is compatible with Afghan society, agreement remained relatively high (61\%) and consistent across all time frames with those from Nangarhar and Qandahar slightly changing heart and disagreeing around their fifth year of service. In fact, an overwhelming $96.3 \%$ believe that voting for political leadership in elections is important for the future of Afghanistan. However, only $2.6 \%$ were satisfied 
with politicians in general. In fact, largely increasing with their time-in-service, nearly half of those polled believe that the political leadership in Kabul only aims to serve their own self-interests (49.8\%).

Arguably, much of this dissatisfaction with the political leadership is rooted in personal grievances and animosities founded on the perception that corruption and favoritism exists among the ranks of the security and defense force and political leadership. More than $68 \%$ of those polled believe that corruption exists among the leadership and ranks of the ANP, including the increasing belief with timein-service that ethnic inequality (75\%) exists where Pashtuns receive preferential treatment (24.7\%). This is particularly worrying when an estimated $72 \%$ believe that armed resistance against those believed to be corrupt is justified. This is heavily the opinion of those polled in Qandahar where an overwhelming $95.7 \%$ believe that armed resistance is justified against corrupt officials. In fact, when asked what was the leading reason for defecting to the Taliban, many (36.8\%) believed that dissatisfaction with the government rather than Taliban influence and coercion (21.3\%) was the main reason, suggesting that most believe that defections are a matter of a push effect consequential to dissatisfaction with the government rather than a pull effect from Taliban influence and coercion among the ranks of the ANP.

Nonetheless, when questioned on their reasoning for joining the security force, most claimed to have joined out of love for their country $(65 \%)$ compared to those who joined for economic incentives (18.5\%), suggesting that voluntary affiliation with the security force is weakly a matter of money. However, those under forty years of age found joining for economic incentives twice as important compared to those over forty. One possible explanation

POTENTIAL FOR VIOLENT RESISTANCE

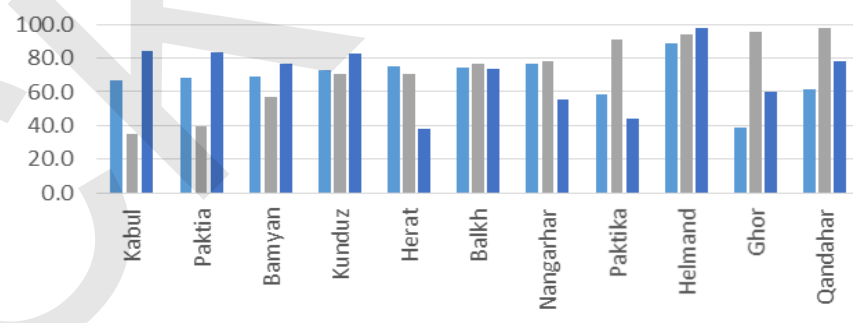

- Officials are Corrupt

Violent Resistance against Corrupt Officials is Justified

Government is Overly Influenced by West for this age based differentiation is that those over forty may have already achieved economic security with higher salaries and cashed in inheritance while younger members of lower ranks continue to strive toward similar security. In fact, when we differentiate between the rank-and-file and officers we find that nearly twice as many rank-and-file $(19.1 \%)$ compared to $13.9 \%$ of officers joined primarily for economic reasons. This prioritization of economic incentives over national consciousness is worrisome, especially when we consider the history of economic based patronage relations in Afghanistan.

The historic approach of Afghan rulers toward organizing its security and defense force were defectively founded on systems of patronage rather than loyalties wherein tribal leaders provided recruits for the security force in return for breaks in taxes, rent-free lands, and other financial incentives. In effect, raising an army to protect one's sovereignty rested on negotiating contracts between leaders of rural communities and central authority. In addition to local community benefits and economic gains for tribal leaders consequential to such patronage relations, individual recruits were also promised some portion of loot and the spoils of war as was the case for raids on rich Moghul territories. This culture of 
patronage help shape a near institutionalized relationship between the government and the people, encouraging more of a hired-hand mentality among the ranks rather than securing the loyalties necessary to achieving legitimacy and national consciousness.

Although findings suggest that most are in favor of democratic governance and leadership, dissatisfaction with corruption and nepotism seems to discourage continued loyalties and in fact promotes a strong sense for violent resistance, especially in Qandahar, Ghor, Helmand, and Paktika. Considered in tandem, corruption among official may lead to a violent response ultimately aimed at reestablishing good governance. However, for the near $20 \%$ who joined specifically for economic gains, the continued hired hand mentality only encourages continued parallel governance and the potential for alternative ideological beliefs to persist.

\section{Views on NATO and Allied Forces in Country}

Demonstrating a poor opinion of NATO and allied forces in country, sentiments of doubt exist in some provinces, such as in Kunduz (9.4\%), Paktika (6.5\%) and Ghor $(6.5 \%)$ where nearly $10 \%$ of those polled believe that the insurgency will not be defeated. Combined with the increasing believe over time-inservice that the Afghan government and politicians are overly influenced by Western values (70\%) and that such institutions only serve foreign interests (8.3\%), both trust and confidence in international forces' presence and success remains sparsely rationed. In fact, when we examine the potential for violent resistance against concerns that the government is overly influenced by the West, there is a suggestion that not only is violent resistance condoned against corrupt officials but that the West has a role in such corruption and as a consequence may also be targeted, especially in Helmand, Paktika, Kunduz, and Qandahar.

This is worrisome when we consider the largely intimate nature of green-on-blue attacks. While it remains possible that the increase in incidents in 2012 may be a direct result of a Taliban campaign, more than 84\% of incidents between 2008 and 2015 were conducted by individuals and of those, 75\% of attacks were directed largely against individual targets, suggesting more intimate motives such as grievances or disputes between assailants and their victims. This is in contrast to insider attacks perpetrated by groups as they are organized and premediated activities suggesting the existence of external interference, support, and motivations.

However, finding out genuine motives for such attacks remain problematic given the limitation and ambiguity of evidence and lack of access. For example, when in 2010 Spanish officers were targeted and killed by their driver in Badghis province and riots followed with hundreds of civilians chanting religious slogans, pelting rocks, started fires, and reportedly shooting at the base, any of a number of explanations could have be called upon. Two years later, in November 2012, Spanish soldiers from the very same base were again targeted. Either individual or community wide grievances could be rationalized, however each would have to be dealt with differently. 
Similarly in another incident, on April 11, 2009, reportedly border police were high on opium when a fight ensued and one policeman was shot dead ${ }^{14}$. On one hand, the potential that grievances were further exasperated by drugs is one conclusion, while on the other it may have been by mere accident.

In yet another incident, an Afghan police woman claimed that she awoke in the morning of December 24, 2012 with the objective of killing 'someone important'. After entertaining and rejecting the idea of killing two female foreign aid workers who were gathering clothes for refugee children, as well as failing to gain access to the Kabul governor's and police chief's offices, she identified, targeted, and at close range shot Dyncorp worker, Joseph Griffin, in the back of the head. Claims range from foreign agent, as she was Iranian and held an Iranian passport, to the possibility that she suffered from psychological ${ }^{15}$ trauma.

While it is clear that finding out genuine motives in these cases will prove difficult, all suggest that a more nuanced vetting and recruitment process is necessary. The initial buildup of Afghan forces was one of hurried ignorance. As a consequence, the security and defense forces suffer high attrition rates, logistical limitations, political factionalism, nepotism, drug use, psychological limitations, and poor education among its ranks ${ }^{16}$. Recruits were young with approximately $30 \%$ having a drug problem, $90 \%$ illiterate, and $25 \%$ prone to desertion ${ }^{17}$. Reportedly, some recruits were also drawn from the very same communities which are or were in revolt against the government and allied forces ${ }^{18}$, leaving trainers to contend with the potential of reprisal from within. In an attempt to remedy these concerns, ISAF and the Afghan Ministry of Interior implemented a re-vetting process as a means to reexamining and weeding out problem cases from the ANDSF.

However, ongoing reliance on local leaders for recruitment recommendations continue to trouble and challenge the vetting and recruiting process with implicit nepotism and competing allegiances and ideologies. Appointed by relatives, recruits often receive preferential treatment, including sympathies in the field and under conflict conditions wherein relatives are pardoned from conducting their duties namely during engagements with insurgents. Not only does this demotivate others from conducting their duty, it also leads to hostility among the ranks, including against allied forces serving alongside these individuals. In fact, as the composition of the security and defense force is largely determined by local tribal leaders, security and defense personnel tend to remain loyal to their local communities. Making matters worse, when posted to their own local communities, loyalties are questionable as security personnel fraternize with locals and prioritize requests from local leaders over that of the central government and allied forces operating in country. Under conditions where ideologies greatly differ, competing priorities may lead to violent resistance and retaliation.

This split between allegiances to the ideologies of centralized democratic governance and that of the periphery becomes more obvious when we polled members on their future ambitions. Of those surveyed, nearly half $(49.8 \%)$ had ambitions to remain under the national government system, either with continued service in the ANP, attendance at the academy (28.2\%), or a political position in Kabul (1.4\%), while approximately $47 \%$ looked forward to returning home to the family business (29.6\%), as local leaders $(2.9 \%)$, or other local civilian work (11.8\%). Just a handful of $3 \%$ wanted to travel abroad 
while only $6(0.4 \%)$ indicated a preference to pursue roles as religious leaders. These findings suggest a near 50/50 split with half of those polled in favor of remaining within the government system while the other half, although not necessary against the central government, prefer to return to local and familiar conditions.

Although it remains difficult to identify the genuine motives behind green-on-blue attacks, this study finds that the authority of both the central government and allied forces functioning in the capacity of trainers and advisors must contend with competing priorities of local governance which may potentially hold alternative ideological beliefs. As a consequence, conditions may easily ripen for the mobilization of security personnel under alternative ideology against the central government and allied forces in country.

\section{Positions on the Prospects of Taliban Governance}

Although an estimated $96 \%$ of those polled believe that the insurgency will be defeated, only $11 \%$ joined primarily to frustrate Taliban operations while increasingly with their time-in-service believe that the Taliban will inevitably join with the Afghan government (63\%). Interestingly, more than $86 \%$ approve of a merger between the Taliban and central government, while more than $31 \%$ continue to believe that the Taliban are still a legitimate source of authority. Moreover, such beliefs remain constant across all time-in-service categories with respondents from Kunduz maintaining a strong and consistent belief, with Qandahar and Nangarhar trailing slightly behind. Such findings suggests that most believe that defeat of the insurgency will conclude with some form of power sharing between the Taliban and the central government. In fact, when asked what the future held for the Taliban, a small portion of the population argued that they will win $(1.4 \%)$, with the greatest number of those from Kunduz believing so $(6.5 \%)$. Nonetheless, the majority of those with over seven years of

\section{LEGITIMACY OF THE TALIBAN}

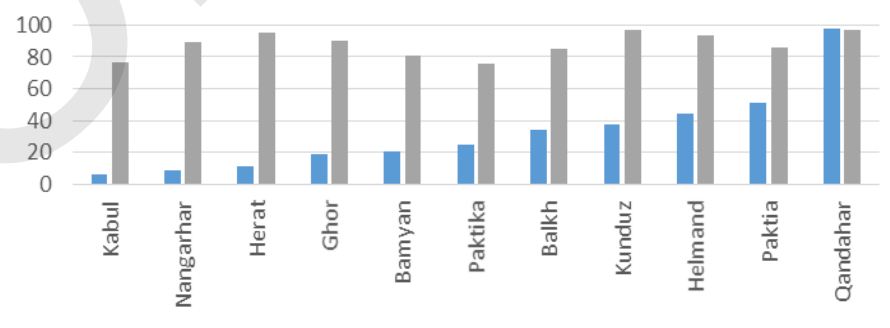

a Taliban is Legitimate Source of Authority naliban should Join the Government service increasingly disagreed with such conclusions.

Taking advantage of the management practices of the security and defense force, local Taliban representatives find the practice of posting security personnel close to their home districts accommodating as they use their familiarity and access to family members as a means of influence or coercion aimed at convincing security personnel to surrender their positions with the police force. In fact, according to one poll, only four out of ten soldiers reenlist after their initial tour ${ }^{19}$ while desertion rates stands at approximately $25 \%$. While posting ANP personnel to their local home communities comes with its benefits, such as an intimate familiarity which provides an intelligence advantage and limits on potential abuse of the local community, counter-influence on local Taliban members remains limited. Arguably, this is on account of the stigma associated with arresting relatives and neighbors, including dishonoring family and neighbors. Although preventing desertion remains a major challenge, 
the co-opting or enlistment of these same highly trained deserters into the ranks of insurgents makes the situation more volatile.

It becomes obvious from these findings that not only do many believe in a future power sharing scheme between the central government and the Taliban, but that the very system which stands in opposition to the Taliban create the opportunity for service member to be influenced and convinced of their legitimacy.

Further corroborating such conclusions, preliminary findings from interviews conducted with senior officials within the security and defense force revealed frustrations over the central government's administration and policy toward its military and police force. In particular, interviewees believe that nepotism and corruption at the highest ranks of the ANDSF inflict damage from the top-down. Moreover, interviewees claim that the rank and file are not convinced that they are fighting for a just cause. Pointing out that harassment by NATO soldiers and negligence which result in civilian casualties drive radicalization, arguably by first offending the honor of family members. However, distinguishing between acting on honor or radicalization remains problematic given the evidence.

With increases of green-on-blue attacks, especially in 2012, NATO revisited the vetting process and made adjustments to improve on screening out potential radical elements from the ANDSF. The updated vetting process consists of eight steps, including medical and drug screening, biometric data collection and check, personal information and photo collection, recommendations and guarantor of personal information verification from two local leaders, valid Afghan identification card, criminal records check, and validation from recruiting authority ${ }^{20}$. However, not all provinces benefitted from improvements and reliance on local leaders' recommendations continue. Moreover, battlefield performance and hostilities is also not remedied.

\section{Summary on Political Deviance}

In summary, key findings of political deviance include:

- Although more than half of those polled have confidence in the office of the President and nearly $80 \%$ participated in elections, perceived corruption and favoritism among the ranks of the security and defense force and political leadership generates the grievances and animosities which encourage service members to turn to the Taliban and other sources of moral governance.

- While more than $68 \%$ believe that corruption exists among political and military leadership, another $72 \%$ believe that armed resistance against corrupt officials is justified.

- An underlining concern for allied forces is the perception that corruption among the security and defense force and political elites has its source in Western intervention. As a consequence, the call for violent resistance may extend beyond members of the ANDSF and political elites to allied forces. 
- While approximately $11 \%$ joined the security force with the objective to securing Afghanistan against Taliban influence, nearly $20 \%$ joined primarily for economic incentives. As a consequence, many maintain a hired hand mentality rather than national consciousness.

- A majority of green-on-blue incidents were of a personal and intimate nature, suggesting that individual grievances, mental states, and ideological beliefs are the underlying motives.

- Many of those polled believe that the future of Afghanistan will see a power sharing scheme between the central government and the Taliban. Posting service members to their home district only further encourage Taliban influence and convincing of their legitimacy.

\section{On Religious Extremism: Religious Beliefs and Interpretation, Tolerance, and Compatibility with Democracy}

This section examines the views of security personnel with regard to their beliefs and interpretations of Islam, their tolerance toward other religions and sects, and their belief in the compatibility of Islam with democracy. As a means for excavating such details, surveys focused on capturing and measuring deviations from moderate views and practices, including views on sectarian relations, justification of armed resistance and violence, and response to the introduction of democracy to Afghanistan.

\section{Religious Interpretations and Beliefs among Security Forces Personnel}

Of those polled, more than $83 \%$ believe that armed resistance by the people against the government is justified if officials are seen as criticizing Islam. In particular, those from Qandahar strongly believed that Muslims have an obligation to take action against those who break with Islamic law and that armed resistance is justified for such cause, despite the presence of security and defense personnel (76.4\%). Those from Kunduz and Nangarhar followed slightly behind with similar views. In fact a handful of those polled, largely from Paktika and Paktia, believe that suicide attacks are a justified means resistance for responding to criticisms against Islam.

Considering green-on-blue incidents and trends, although most perpetrators were killed in return fire by either domestic or foreign security personnel, it cannot be definitely argue that such consequence were part of planned suicide missions. On one hand, there were a relatively small number (5\%) of suicide bombers and self-inflicted small arms suicides which may be interpreted as motivated by underlying extremist interpretations and radical ideology. On the other, perpetrators may have chosen to take such actions out of desperation.

JUSTIFICATION OF ARMED RESISTANCE IN THE NAME OF ISLAM

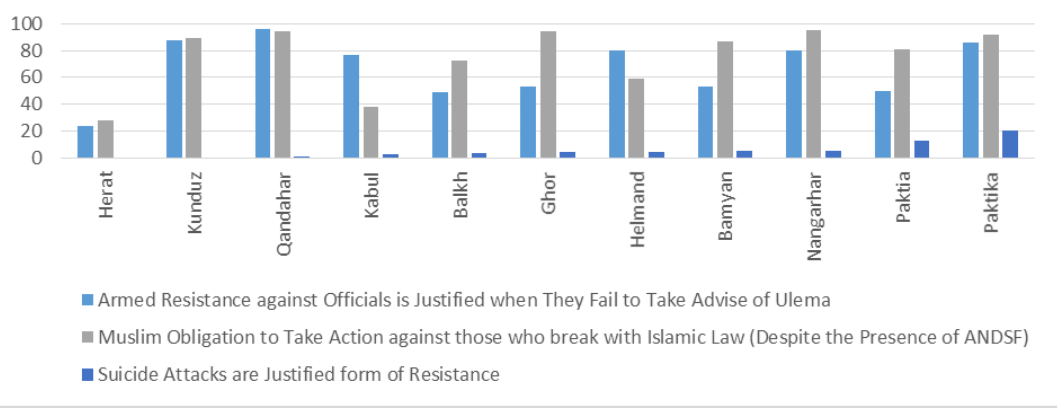




\section{Religious Tolerance and Inter-Ethnic and Sectarian Fraternity}

Increasingly with their time-inservice, more than $67 \%$ of those polled believe that most religious faiths provide a positive contribution to society, while nearly $90 \%$ believe that all religious faiths are worthy of respect. In fact, when examining views on more intimate relations

RELIGIOUS TOLERANCE

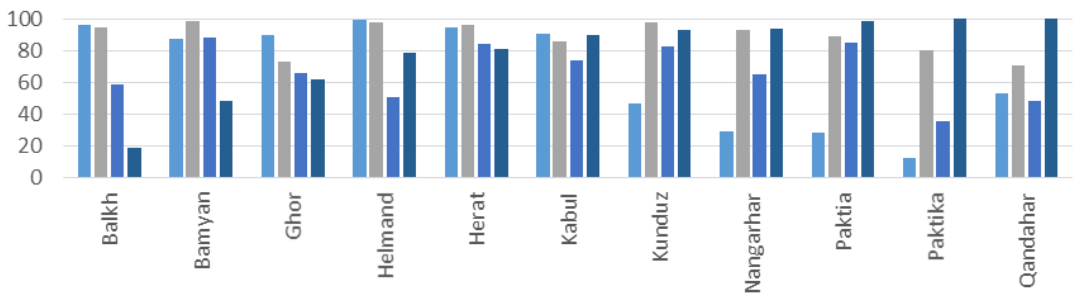

= Most Religions Positively Contribute to Society a All Religious Faiths are due Respect

- Appropriate to Marry into other Religious Sect — Establishing Caliphate is Duty of all Muslims

between Muslims and non-Muslims nearly $90 \%$ believe that Muslims are allowed to enter into negotiations and peace agreements with non-Muslims, while a similar number approve of non-Muslims moving into their neighborhoods and even next door with an estimated $75 \%$ believing that it is permitted to eat at the same table with non-Muslims. However, nearly $80 \%$ of these same respondents also believe that it is a duty of all Muslims to establish a Caliphate, suggesting that there is a belief among members of the security force that tolerance to other religions and the establishment of a Caliphate are not contentious or contradictory.

Similarly, of those surveyed nearly $98 \%$ believe that all religious sects (mazha) and their practices should be respected. In fact, nearly $70 \%$ believe that it is appropriated to marry outside one's religious sect. Such estimates are particularly important as only $7.5 \%$ of those polled believed that the main reason for conflict in Afghanistan is religious in origin, compared to those who believe that manipulation by foreign countries $(57.9 \%)$ or ethnic issues $(23.4 \%)$ are to blame.

In fact, a senior military official interviewed in the preliminary stages of this research claims that Afghans are increasingly conforming to change with greater sectarian tolerance, especially in response to both Sunni and Shia imams' decree that no one should be attacked as apostate or kafir who commits to regular prayers, neither Sunni nor Shia ${ }^{21}$.

However, ethnic tension exists and is reported as a comparatively much stronger reason for conflict than religion, except for Helmand province where religion is seen as slightly more of a driver of conflict. In fact, increasingly with their time-in-service security personnel believe that ethnic inequality exists among the

REASON FOR CONFLICT IN AFGHANISTAN

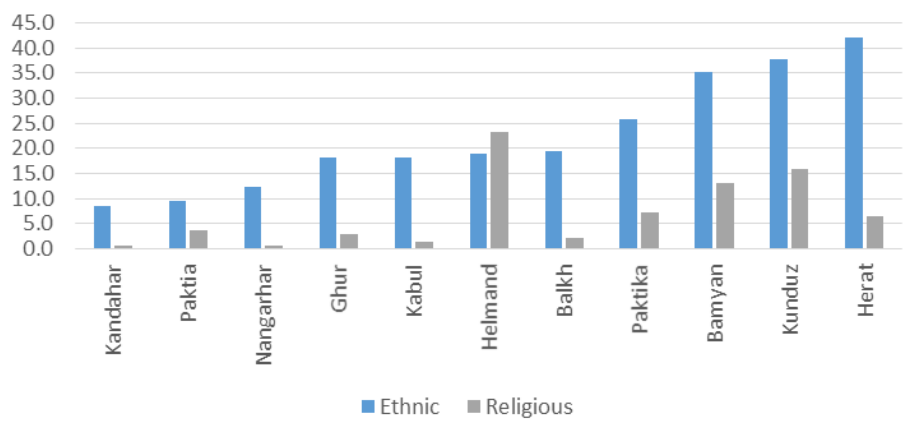


ranks of the security force; those from Herat, Kunduz, Bamyan, and Paktika claim more so than other provinces.

This is particularly worrying, especially when considering the potential limitations in the reach and exercise of the duty of security and defense personnel in ethnically sensitive environments. In fact, any proposition to rotate personnel across districts will have to manage the distribution accordingly, especially when moving personnel from the north and west to the south and east as such moves have the likelihood of further provoking ethnic tensions and discrimination, a source and fuel for propagating and acting on radicalized ideology.

\section{Views on the Compatibility of Islam and Democracy}

Of those polled, more than $96 \%$ believe that the Afghan government is a legitimate Islamic regime while more than three-thirds find that the Taliban were not good religious leaders (76.6\%) and that they did not follow true Islamic values (94.7\%). However reflecting the contrary, more than $76 \%$ of those from Paktia province believe that the Taliban were once good religious leaders while those from Qandahar and Helmand province remained more optimistic of Taliban religious credentials with more than 13\% from each province finding that the Taliban follow true Islamic values. Such findings suggest that of those polled, respondents from Paktia, Qandahar, and Helmand hold the most conservative views with Kunduz, Balkh, and Paktika following slightly behind with an average of $25 \%$ from each province trusting in the religious leadership of the Taliban. When we consider that less than $12 \%$ of security personnel claim to have joined with the main intention of countering the insurgency, these findings suggest that sympathy toward the Taliban exists among the ranks of the security force. Of particular interest is that of those polled, more than $79 \%$ believe that establishing a caliphate is a duty of all Muslims, suggesting that a large portion of the security force find religion as a guiding governance principle - some provinces much more conservatively than others. However, while much of Western interpretation erroneously believe that establishing a caliphate means domination over other religions, it is more commonly understood by Muslims as the process of spreading the word and developing brotherhood in the same manner as Abraham, Moses, and Jesus $^{22}$.

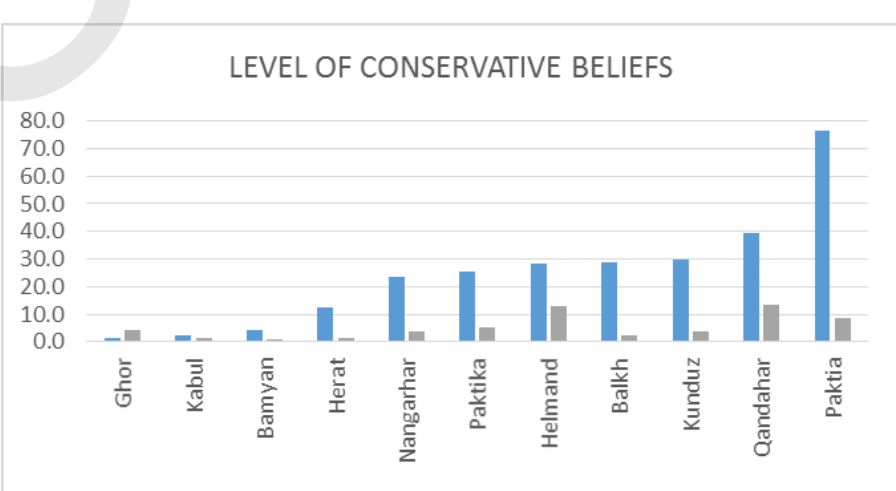

- Taliban Good Religious Leaders Taliban follow True Islamic Values

Nonetheless, optimistic opinions in favour of the Islamic values of the Taliban change over the course of service members' time-in-service with members from across all provinces increasingly disagreeing with Taliban ideology. Demonstrating the differentiation in views over both time and space, those with less than one year of service from Qandahar, Nangarhar, and Helmand ranked as the most conservative and in favour of Taliban religious values and leadership. 
Checking views on the compatibility of Islam with democracy, those from Paktika and Kunduz disagree more than those from other provinces finding that democracy is largely not compatible with Afghan society while believing that the establishment of a caliphate is a duty of all Muslims, suggesting a relatively stronger believe that religious leadership without democracy is the preferred governance form for Afghanistan. Surprisingly, those from Qandahar find more than those from other provinces that democracy and the establishment of a caliphate can function in parallel.

COMPATIBILITY BETWEEN ISLAM AND DEMOCRACY

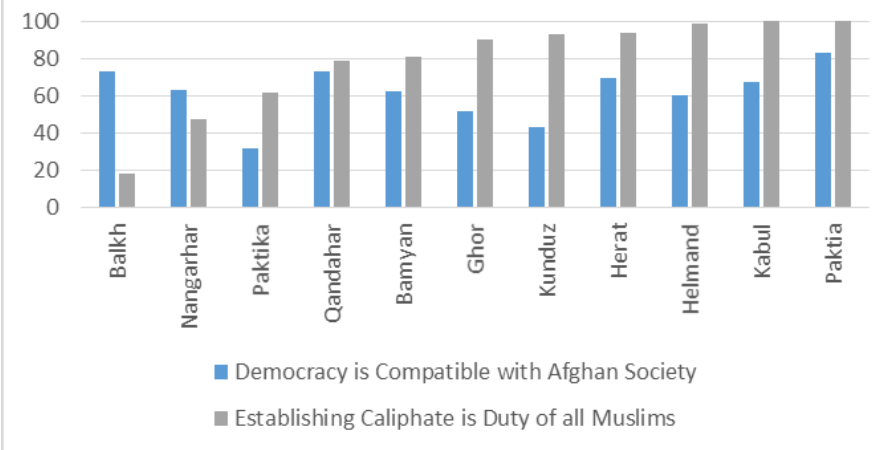

A senior security officer interviewed claimed that any armed revolt against the state will have to be a consequence of first earning the favor and then the mobilization of people under counter-narratives and assumptions of the proper governance structure for Afghanistan, one that may see even more conservative and potentially extreme law and governance. Indeed according to this same official, with the influx of more than 30,000 foreign fighters into Afghanistan during the 1980s confrontation with the Soviets, the seed of radicalized ideology and in particular the notion of takfir spread across Afghanistan as a means for mobilization of large parts of the populations. Given the findings of this section, some provinces remain ripe for similar circumstance. In fact, this same official was keen to mention that while up to the Second World War Afghanistan remained relatively isolated, it was exactly such isolation which encouraged the people to appreciate their Afghan culture and ultimately come to reject the extremes of both the Muslim Brotherhood and communism.

As part of his 2011 Eid message, then Taliban leader Mullah Mohammad Omar acknowledged that infiltration into the ranks of the security and defense apparatus was one pathway toward imminent victory $^{\prime 23}$ and in the following year's message he claimed that "Mujahidin have cleverly infiltrated in the ranks of the enemy according to the plan given to them last year" ${ }^{24}$, suggesting that the increase in incidents during 2012 was a direct consequence of his plan and orders. In fact, 11 of the 45 or nearly $25 \%$ of green-on-blue incidents in 2012 were conducted by groups of security and defense personnel and not lone actors, suggesting coordination and preplanning. Moreover, 4 out of the 11 insider attacks perpetrated by groups of security and defense personnel were from Qandahar, one of the most conservative and Taliban friendly province.

\section{Summary on Religious Extremism}

In summary, key findings of religious extremism include:

- With $83 \%$ of those polled believing that armed resistance is justified against those who criticize Islam and $76 \%$ of those from Paktia believing that the Taliban are good religious leaders, findings suggest that those from Paktia may put up armed resistance against criticism to Taliban ideology. 
- Similarly, a handful of those from Paktika and Paktia find, more than those from other provinces, that suicide attacks are a justified form of armed resistance suggesting further that criticism of Taliban ideology in these provinces may be met with suicide attacks.

- More than $76 \%$ of those polled from Qandahar believe that armed resistance is justified even in the presence of security personnel, suggesting that many believe the security force may be circumvented in the process of standing up for religion.

- Although this study finds that most are tolerant of ethnic and religious differences, increasingly nearly $25 \%$ believe that ethnic discrimination is a primary cause of conflict in Afghanistan. Arguably, such conditions limit the reach of security personnel on account of their ethnicity.

- Relative to other provinces, those from Paktika and Kunduz find more so that democracy is not compatible with Islam. These same respondents are also strongly in favor of establishing a caliphate, suggesting that many from Paktika and Kunduz believe in religious leadership without democracy.

\section{On Social Intolerance: International Norms and Values, Women and Human Rights, and Afghan Society}

The social intolerance indicator estimates the extent to which individuals are receptive to and appreciative of internationally accepted norms in general and more specifically the extent to which they find it compatible with Afghan culture. In particular, we examine views on international conventions on women and human rights and the right of intervention in the case of violations; the relationship between these conventions and Islamic values; the extent of the legal legitimacy of international law over other legal structures in Afghanistan, and ethnic and religious tolerance.

\section{Views on Women and Human Rights}

When polled on the rights of women, nearly $95 \%$ believed that women should be allowed to serve as ministers while 92\% submitted that Afghan values agree to women taking part in political activities. In fact, $89 \%$ claimed that they would work for a woman commander. Moreover, near similar numbers claim that they have no problem with marrying employees of the government or civil society organizations (85\%). However, while 91\% believe that both men and women have the right to

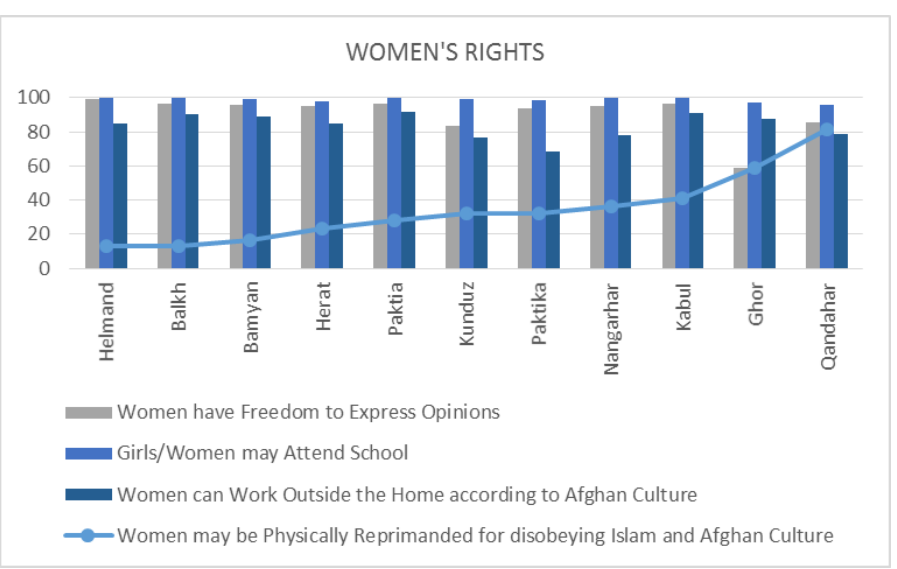
freely express their opinions, a smaller number believe that Islam allow for women to work outside the home (84\%). Although most believed that girls should attend school (98.9\%) and $90 \%$ believe that violence against women is not acceptable, there remained less who believed that women should have all the same rights as men (78.9\%). Such sentiments were strongest in Qandahar where over $80 \%$ approve of physically reprimanding women for disobeying Islamic law or disrespecting Afghan culture. 
Examining respondents' views on international conventions on women and human rights, surveys suggest that relative to other province, Qandahar maintained a relatively higher level of intolerance across all time-in-service categories where approximately $60 \%$ of those polled believed that Afghans have no obligations to agree with or accept international conventions on women and human rights. Kunduz also remained relatively high with nearly $40 \%$ believing similarly up to the seventh year of service with increasing agreement and acceptance of international conventions thereafter. Respondents from Qandahar similarly felt relatively stronger against allowing women to serve as ministers, with increasing intolerance up to the seventh year of service where more than $14 \%$ were against women serving as ministers. Thereafter, slow acceptance took hold. When questioned on their views on whether women could more broadly take part in political activities, respondents from Qandahar again exhibited relatively stronger sentiments against women participating in political activities up to the seventh year of service, followed by gradual acceptance thereafter. Respondents from most other provinces demonstrated increasing acceptance for women in politics over their time-inservice.

Again, when asked if they would consider working for a woman commander, most provinces increasingly with time-in-service agreed. However, both Qandahar and Nangarhar remained relatively high in disagreement, with those from Qandahar increasingly negative between their fifth to seventh years of service, followed by a slow rate of approval thereafter.

On the broader question of whether women should be permitted to work outside their home, where most provinces remained relatively positive across all time frames, Ghor and Qandahar both maintained relatively higher levels of intolerance with slow levels of acceptance beginning after the seventh year of service.

On a more pointed question, when asked whether women can be physically reprimanded for disobeying traditions of Afghan culture and Islam, Qandahar and Ghor both maintained relatively high levels of agreement across all time frames, while Nangarhar, and Paktia saw a decrease in agreement up to the fourth year of service followed by relatively consistent agreement. Respondents from other provinces maintained their disagreement against physically reprimanding women for disobeying traditions of Afghan culture and Islam.

Views on the Compatibility of International Norms and Values and Islam

When asked if they believed that Afghans have a duty to follow international conventions on women and human rights, more than $80 \%$ agreed, with this number increasing with time-in-service. In fact, more than $70 \%$ agreed that the international community has the right to intervene and prosecute violators of the international conventions on women and human rights. However, when asked whether international norms and values were in line with Islamic values, nearly half (48\%) disagreed,

COMPATIBILITY: ISLAM AND INTERNATIONAL LAW

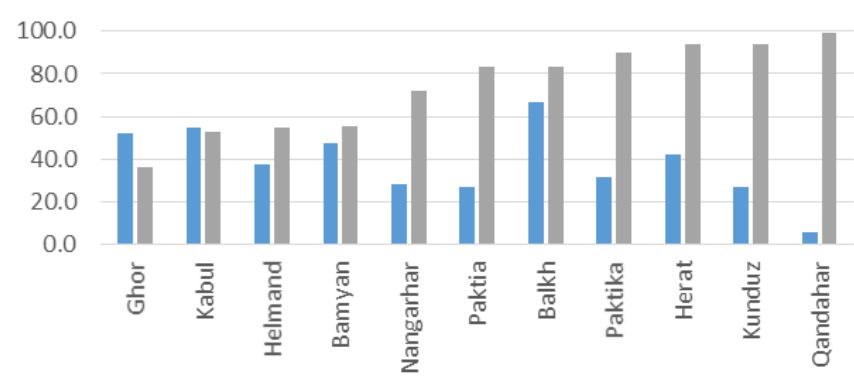

- International Norms and Values are Compatible with Islamic Values neligious Law Supercedes International Law 
suggesting that while international conventions on women and human rights may not necessarily be in line with Islam, they remain somewhat supported. Of the $20 \%$ who disagreed with the conventions and the approximate $30 \%$ who were against international intervention in the case of violations, nearly $60 \%$ received only religious education. In fact, increasing education levels saw increasing agreement with both the duty to follow internationally accepted norms and values and the international community's right to intervene and prosecute violators. There were no visible trends across age groups except for the maintenance of a relatively high average of $42 \%$ in agreement that international norms and values are in line with Islamic values.

\section{Views on the Compatibility of International Norms and Values within Afghan Society}

Considering Islamic values and its compatibility with internationally accepted norms and values, while up to the seventh year of service Nangarhar saw increasing acceptance of international norms and values, Qandahar demonstrated the contrary with more than $14 \%$ believing that international norms and values are not in line with Islamic values. When asked whether Muslims could make peace agreements with non-Muslims, respondents from both Ghor and Qandahar disagreed across most of time frames, only tapering off beyond the ten year mark while respondents from Nangarhar and Balkh increasingly disagreed.

COMPATIBILITY: AFGHAN SOCIETY AND INTERNATIONAL LAW

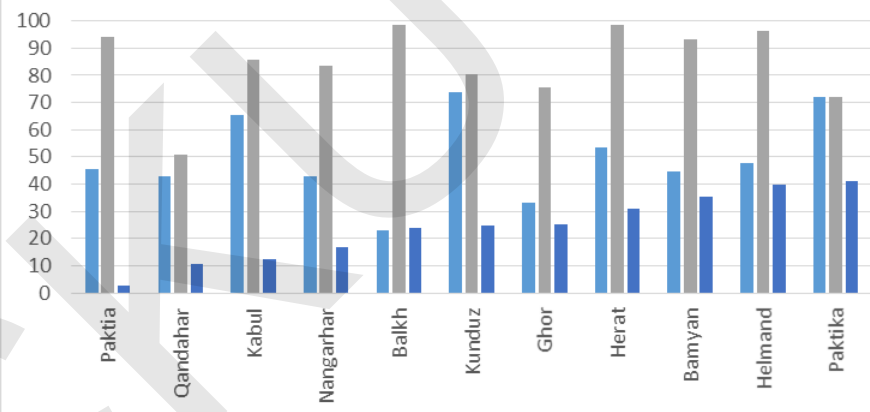

- Religious Jurisdiction a Afghan Govt Jurisdiction = International Law Jurisdiction

In the case of legitimate authority, nearly $73 \%$ agree that sharia law supersedes internationally accepted norms and values, with Kunduz (89.9\%) and Qandahar (99.3\%) ranking high on the poll. On the other hand, more than half of those polled disagreed that traditional law and jirga supersede international norms and values. However, Qandahar again ranked high with more than $42 \%$ submitting that traditional Afghan law supersede international law. Only $25 \%$ believed that international law could replace domestic national laws, with nearly $60 \%$ disagreeing. With regard to domestic jurisdiction over women and human rights, more than $60 \%$ believe that sharia law is the final authority on the matter, while central government authority fell in second place with $19 \%$ believing that jurisdiction and final authority rested

LEVEL OF ACCEPTANCE OF INTERNATIONAL NORMS AND VALUES

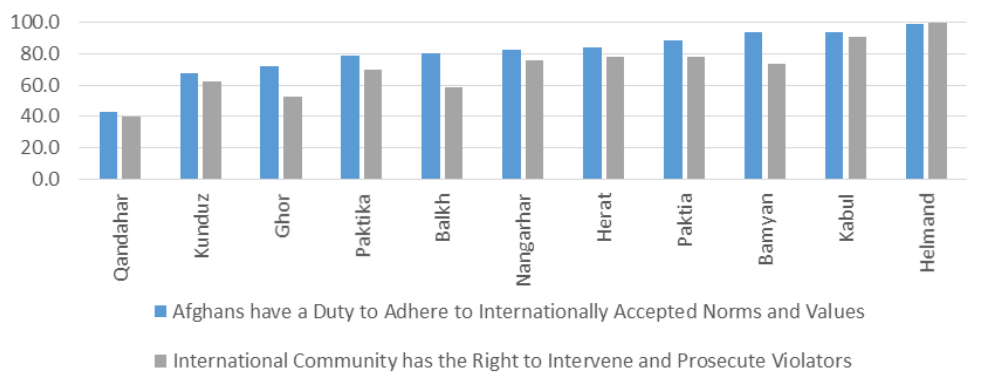
in the Office of the President and legislature. 
International intervention undoubtedly introduces some level of competition between domestic and international values and ideologies, while the level of domestic receptivity determines the extent to which the application of foreign sponsored policy and programs will be successfully implemented. Arguably, compromise is needed to determine what is indispensable to meeting stability in Afghanistan and that which is too ambitious.

\section{Summary on Social Intolerance}

In summary, key findings on social intolerance include:

- $\quad$ Although nearly $95 \%$ believe that women should be allowed to work outside the home, less believe that Islam allow such rights for women (84\%).

- While more than $90 \%$ believe that violence against women is not acceptable, more than $80 \%$ of those polled from Qandahar approve of physically reprimanding women for disobeying Islamic law or disrespecting Afghan tradition and culture.

- Approximately $60 \%$ of those from Qandahar and $40 \%$ of those from Kunduz believed that Afghans have no obligations to agree with or accept international conventions on women and human rights.

- Nearly half (48\%) believe that international conventions on women and human rights may not necessarily be in line with Islam; $60 \%$ of this same population received only religious education. In fact, increasingly with education levels, there is agreement on the compatibility of Islam with international conventions.

- Nearly $73 \%$ agree that sharia law supersede international conventions with $60 \%$ believing that sharia law has final jurisdiction and authority over women and human rights.

\section{Relative Level of Radicalization across Provinces}

Examining the relative level of radicalization across provinces, this study finds that Qandahar is the most conservative province of the eleven with most respondents holding relatively stronger views of social intolerance, religious extremism, and political deviance. Paktika ranked second to Qandahar with regard to social RELATIVE LEVEL OF RADICALIZATION

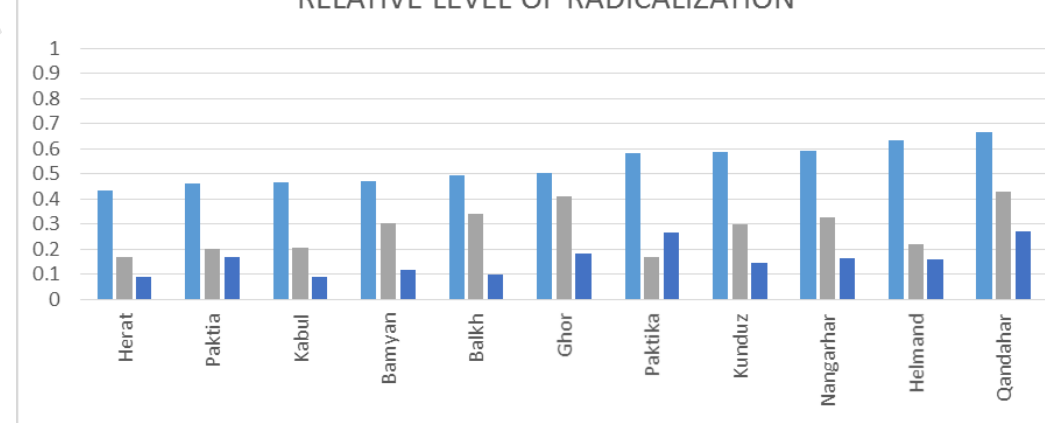

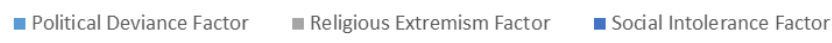
intolerance, while Ghor ranked second against Qandahar with regard to religious extremism. On the measure of political deviance, Helmand ranked second after Qandahar with Kunduz, Paktika, and Nangarhar following closely behind. In particular, while the views on the rights of women and the acceptability of international norms and values varied across provinces, more than $80 \%$ of those from 
Qandahar approved of physically reprimanding women for disobeying Islamic law or disrespecting Afghan tradition and culture, while nearly half of those polled from Qandahar and more than $30 \%$ of those from Kunduz believe that international conventions on women and human rights are not necessarily in line with Islamic values.

An examination of the distribution of green-on-blue incidents seem to coincide with these findings with a greater number of incidents in the south (43\%), particularly in Helmand and Qandahar, compared to other areas in Afghanistan. In fact, some argue that a 'greater degree of coordination ${ }^{25}$ is also evident in Helmand, suggesting the potential of external support and direction either from local communities or insurgent groups.

\section{CONCLUSIONS AND RECOMMENDATIONS}

This study concludes that while most security personnel over the course of their career accept centralized democratic governance, conservative views leaning toward extremist ideology persists among the ranks of security force personnel in some provinces.

- While survivorship bias is a reasonable consideration when examining individual provinces in absolute terms, in relative terms findings suggest that differences across provinces are a result of influences native and specific to provinces and differentiated programming of personnel across ANP posts. In fact, service members' response to the inherent tension and competition between local influence and that of the central government authority manifest in their obligations as security personnel serves as a measurement tool of their political deviance.

- As indications of the extent of political deviance, local influences from the most conservative provinces, such as Qandahar, not only contest security personnel meeting their obligations, but also support direct and violence defiance of military and political leadership. Not only does such influence limit the reach of the central government and the enforcement of law, it also advocates extremist and violent behavior which ultimately undermines the legitimacy of the central government and its domestic sovereignty. Moreover, with the withdrawal of international forces and the loss of its mustering capacity, it may be just a matter of time before security personnel fragment along provincial, district, and even village lines as a consequence of their local ties and affiliations. Most worrying are the more conservative districts and provinces where extreme ideology persists among security personnel who elect to defect back to their local communities and its leadership.

- In some of the most conservative provinces, such as Kunduz where many believe that democracy is not compatible with Islam, and Paktia and Paktika where nearly $10 \%$ of those polled believe that suicide attacks are a justified form of armed resistance, counter-narratives

must contend with and meet the geographical distance and spillover of ideology from bordering countries. Indeed, it is not a coincidence that the most conservative provinces rest in the 
distant periphery and on the border with neighboring states and their own largely autonomous and conservative regions. Obstructing the spread of radical ideology while promoting national consciousness in these provinces demand more than the standard indoctrination of security personnel as ideological competition is at its fiercest in these provinces.

- Grievances and animosities incited by nepotism and favoritism have led to the disrepute of military and political leadership and the provocation of violence among the ranks of the security force. Although at times interpreted as ethnic discrimination, nepotism and favoritism have resulted in the very same violence which instigated attacks against foreign forces and saw the defection and desertion of others. In fact, most green-on-blue incidents were found to be motivated largely by individual grievances, suggesting that nepotism and favoritism may be one underlying cause of insider attacks

- Increasingly with their time-in-service nearly a quarter of those polled believe that ethnic discrimination exists and is a primary cause of conflict in Afghanistan. Inter-ethnic and sectarian fraternity is a crucial first step toward meeting a unified Afghanistan founded on national consciousness. However, Afghanistan has a history of difficulty in meeting and maintaining such unity. As the Afghan security force is meant to enforce laws which protect the rights of all citizens, irrespective of ethnicity and sect, ensuring inter-ethnic and sectarian fraternity among the ranks is vital to meeting broader social tolerance.

- Dependence on local tribal leaders for the endorsement and recommendations of recruits arguably is a process built on patronage and nepotism which find recruits torn between the ideology of their patron and that of the central government. More importantly, failure to divorce security personnel from ties with their local communities and its leadership enables locally held ideologies to persist among the ranks of security personnel even in the face of training and indoctrination aimed at instilling moderate ideology. For example, competing interpretations of women and human rights continue to find those in the most conservative provinces approving of the physical reprimanding of women and the complete dismissal of internationally accepted norms and values as un-Islamic. History demonstrates an all too customary tolerance to autonomous rule in the periphery which undoubtedly allows competing ideologies to persist. Centralized democratic governance is not compatible with such fragmented organization of domestic sovereignty. Not only does the passive consent for such parallel and competing authority directly oppose and contradict programs set up to drive moderate behavior and beliefs among security personnel, it reflects poorly on the level of compliance of the state to internationally accepted norms and values.

- Those with lower education levels tended to have stronger radicalized ideology, such as intolerance of other religions and sects and the advocating of violent retaliation against nonMuslims. With more than $90 \%$ of recruits found to be illiterate, such correlation between education level and radicalized ideology is worrying. Moreover, although recruits have to participate in a 65 hour literacy training program, follow-up training and further education remains limited, and given the existence of nepotism and favoritism, it is highly likely that 
opportunities are mismanaged. Making matters worse, trainers and mentors find themselves exposed when uneducated security personnel grow reluctant and derelict, leaving a sense of animosity and the potential conditions for violent retaliation.

In addition to the more than $\$ 65$ billion already spent by the US to build the ANDSF from the ground up, during the May 2012 Chicago summit North Atlantic Treaty Organization (NATO) members agreed to continue financial support until 2024 when Afghanistan is expected to take over financial responsibility ${ }^{26}$. As part of this transition, members also discussed reducing the current strength level of 328,805 to $228,500^{27}$ personnel, which is estimated to cost $\$ 4.1$ billion annually to maintain. The decision to reduce strength levels remains based on security needs and the collective discretion of both the Afghan government and the international community. This report finds that the effectiveness of ongoing financial support is limited and may in fact support the very conditions which encourage personnel to submit themselves to radical ideology, such as driving corruption among leadership or empowering those who hold competing ideological beliefs with financial strength. Meeting such competing ideology is an indispensable first step toward enhancing the legitimacy of the central government and improving the effectiveness of ongoing support.

\section{The Ministry of Interior}

- Should address concerns over corruption within the ranks of the ANP and among its military and political leadership as corruption is seen as justification for circumventing the authority of security and defense personnel and taking up arms against the leadership. Initiatives aimed at ending nepotism and other patronage links and the institution of oversight programs are first steps toward encouraging trust and reducing the likelihood of insurrection among the ranks of the ANP. Although any program aimed at reducing and eliminating corruption is expected to be met with provocation and resistance, the very process itself demonstrates an attempt to institute fairness among the ranks and as a result, may help to reduce the tensions and animosities which led to personnel taking up arms against each other. Most importantly, anticorruption programs must be permanently instituted with third party oversight, rather than a temporary fix managed by local personnel. This is key to limiting conflicts of interest and maintaining neutrality, as well as the means for maintaining pressure against potential corruption.

- Should revisit recruit and follow-on curriculum, specifically addressing the development of national consciousness and meeting misunderstandings over the compatibility of international norms and values and Afghan society and culture. Initiatives should standardize training programs which indoctrinate personnel on democratic values, government authority, and the role of its security and defense force to uphold the law and maintain a monopoly on the legitimate use of force. Although this study finds that the culture and absorption rate of such curriculum differs across provinces where the most conservative provinces will demonstrate greater resistance, the expectation is that over time and with an increasingly literate security force, increased understanding and acceptance will lead to a stronger national consciousness. 
- Should institute rotation tours of rank-and-file personnel and/or officers as a means of severing ties with local communities and the potential for ongoing ideological competition. Failure to divorce security personnel from ties with their local communities encourages tensions and competition between local ideologies, including Taliban and other influences, and that of the central democratic government. Although a very sensitive process which is bound to be met with resistance, it is the first step toward breaking with local ideological competition and the advancement of a national consciousness. Nonetheless, local tradition should be promoted as part of this national consciousness in order to demonstrate respect for local tradition while reiterating its subordinate position with respect to the greater ideals of statehood.

- Should institute training on psychological operations and counter-influence techniques to meet with the influence and coercion tactics of local Taliban members. Whereas much of the opposition against insurgent forces has been demonstrated in the streets and mountains with armed resistance, little has been done to meet with the narratives of local Taliban members. This is particularly so with regard to influence/counter influence narratives between local Taliban members and security force personnel. Obviously, convincing security personnel that their cause is a just one is a first step toward employing them as messengers of influence, however once accomplished counter-influence techniques are a sure means for extending the reach of the central government and for bringing the message of national unity to the local communities.

\section{The Ministry of Health}

- Should oversee the development of initiatives aimed at initial and ongoing evaluations of the psychological health of service members. Personal grievances and animosities among members of the security force, ultimately provoke violence among its ranks, including against foreign forces, and potentially lead to defection or at least desertion. Also, as most incidents of greenon-blue attacks were personal and intimate in nature suggesting that individual grievances and personal ideological beliefs were the underlying motives rather than collective action, particular attention in these areas are a first step toward reducing insider attacks. Finding and keeping on staff qualified health care practitioners remains a challenge as the numbers are thin. However, contracting foreign assistance for such an intimate process is not recommended as the nuances of differentiated cultures inevitably will lead to misunderstandings and misinterpretations. Rather, funding should be allocated to training more indigenous health care workers in the practice of psychological evaluation.

\section{Directorate of Religious Education and Training, the Ministry of Hajj and Religious Affairs}

- Should institute programs under the management and direction of uniformed religious leaders which address concerns over the compatibility between Islamic values and internationally accepted norms and values. In particular, the Directorate of Religious Education and Training should work with the Ministry of Interior and the security force to develop, standardize, and institute across all provinces religious curriculum which specifically addresses concerns over the 
compatibility of Islamic values with internationally accepted norms and values. Similarly to the institution of other programs, conservative provinces will prove more difficult to deal with. However, over time incremental absorption is expected to take hold. 


\section{ANNEXES}

Annex 1: Statistics on the Afghan National Security and Defense Force

This annex provides both a general demographic assessment and distribution of participants and a broader survey of the statistical make-up of the Afghan National Security and Defense Force. A review of the demographics of the sample population provides the requisite understanding of the overall composition of the ANP that is needed for targeted policy application.

Of those polled, nearly three-quarters had served between one and four years (68.1\%) with the ANP, while a majority were between the age of 21 and 30 (67.6\%) with an ethnic breakdown of Pashtuns (40\%), Tajik (25.8\%), and Hazara (20.9\%). Other groups, such as Uzbeks (3.3\%) trailed behind. Sunnis accounted for more than $78 \%$ of those polled, while Shia account for less than a quarter (21.7\%). More than $70 \%$ were married while only $3 \%$ of respondents were women. Only two respondents participated in DDR programs. More than half or $54.9 \%$ of those polled had engaged in combat with insurgents at least once.

Slightly more than a quarter of those surveyed were illiterate (26.7\%), with Helmand (63\%) ranking the most illiterate followed by Paktika (43.9\%), and Qandahar (39.3\%). One-third completed primary school (33\%), while nearly another one-third completed their high school education (30.5\%). Of the remaining, $6.8 \%$ completed their bachelors' degree while 49 respondents completed only religious education (3\%). Less than one-tenth of a percent completed their masters' degree $(0.1 \%)$. Comparing provinces, Nangarhar is the most educated with $25.4 \%$ completing their bachelor degree, with Kunduz (13\%) and Kabul (12.3\%) following behind. Nearly half the population polled in Kunduz (44.2\%), Kabul (44.9\%), and Bamyan (44.6\%) completed their high school education, while those from Paktia ranked relatively low with half the population sampled (56.6\%) completing only primary school education. 


\begin{tabular}{|c|c|}
\hline COMPONENT & STRENGTH LEVEL \\
\hline Afghan National Security Force & 328,805 \\
\hline Men & 326,805 \\
\hline Women & 2,000 \\
\hline Afghan National Army Total & 176,762 \\
\hline Afghan National Army Regular Units & 141,928 \\
\hline Afghan National Army Special Forces & 11,000 \\
\hline Afghan Army Air Force & 7,000 \\
\hline Afghan National Army Civilians & 7,096 \\
\hline Afghan National Police Total & 155,182 \\
\hline Afghan Uniformed Police & 95,389 \\
\hline Afghan National Civil Order Police & 15,017 \\
\hline Afghan Border Police & 22,021 \\
\hline Afghan Anti-Crime Police & 3,400 \\
\hline Afghan Public Protection Force & 16,483 \\
\hline Afghan Local Police & 28,376 \\
\hline Afghan Special Narcotics Force & 2,759 \\
\hline \multicolumn{2}{|l|}{ Ethnicity (Polled) } \\
\hline Pashtun & 662 \\
\hline Hazara & 346 \\
\hline Tajik & 427 \\
\hline Uzbek & 54 \\
\hline Turkmen & 15 \\
\hline Others & 153 \\
\hline \multicolumn{2}{|l|}{ Age (Polled) } \\
\hline$<<21$ & 226 \\
\hline $21-30$ & 1120 \\
\hline $31-40$ & 258 \\
\hline $41-50$ & 38 \\
\hline $51-60$ & 14 \\
\hline$>60$ & 1 \\
\hline
\end{tabular}


Annex 2: Research Design and Methodology

For this study, 1,498 uniformed rank and file personnel, 151 commissioned officers, and 8 uniformed religious leaders based across 11 provinces in Afghanistan, including Balkh, Bamyan, Ghor, Helmand, Herat, Kabul, Qandahar, Kunduz, Nangarhar, Paktia and Paktika completed a 30 question survey administered by field researchers.

The team of field researchers comprised of twenty-two university graduates of political science, international relations, law, education, business, literature, physics, computer science, sociology, and journalism who have no affiliation with the ANDSF, but are local residence of the province in which they conducted surveys. In addition to receiving a formal two day training in Kabul on research ethics and procedures, each field researcher also completed an ethics review form and worked under the supervision of the Head of the Department of Peace Studies. Field researchers coordinated and scheduled field surveys with the Directorate of Police and were granted permission to visit a number of posts within each province. Surveys were first constructed in English and then translated into Dari and Pashtu for distribution and administration. In addition to completing individual surveys, each field researcher manually entered surveys into Excel spreadsheets which were received by the Head of the Department of Peace Studies where data was compiled using SPSS and translated back to English for examination.

A number of complications were met in the field. First, while the original direction of this research aimed to examine both the ANP and ANA, difficulty with access to military personnel as a consequence of ongoing conflict in a number of provinces influenced the Afghan Ministry of Interior's decision to deny access. Access to ANP was also delayed as a consequence of similar conditions as well as typical bureaucratic procedures and delays.

While in the field, researchers were also confronted by and reported on a number of difficulties. For example, in the third district in Kabul resistance was evident while in one station as members of the ANP ask for compensation for their time. Similar resistance was reported in Herat, where reported interviewees became cautious when answering demographic details. Also, although researchers purposely strived to maintain trust by explaining our confidentially obligations, it was evident that interviewees were cautious with their answer, particularly with regard to questions on the Taliban. Reportedly, caution was a consequence of local commanders' failure to explain to interviewees about the project. In fact, when commanders explained to interviewees, some still remained uncooperative. In Ghor, reportedly some interviewees outright did not answer some questions resulted in a handful of 'no response' answers. Some, such as in Bamyan, reported did not initially take surveys seriously, especially as they remained committed to their daily routines. Such caution was also reported in the provinces of Balkh. Another reported difficulty included illiteracy and comprehension of questions; this was reported in Nangarhar, Balkh, Helmand, and Ghor. Field researchers reported spent time explaining each question. In Herat, field researchers reported came across underage ANP personnel whom they elected not to survey. Finally, as the survey coincided with the month of Ramadan some interviewees were reluctant to province their time. In addition to security concerns, a lack of coordination between 
the police departments in Nangarhar posed some difficulties. Even when presented with authorization letters from the Ministry of Interior, security staff remained resistant. Also, some questions were not answers, leading us to code entry as no response (NR) or don't know (DK). It was reported that field researchers could not force answers. 


\section{References}

${ }^{1}$ Bill Roggio, "Taliban Claim Insider Attack at Kabul Airport That Killed 3 Us Contractors," (Washington: The Long War Journal, 2015).

${ }^{2}$ Associated Press, "Us Soldier Shot Dead in Afghanistan 'Insider Attack'," The Guardian 2015.

${ }^{3}$ Bill Roggio, "4 Isaf Soldiers Killed in Suicide, Green-on-Blue Attacks," (Washington: The Long War Journal, 2014).

${ }^{4}$ Seth G. Jones, Counterinsurgency in Afghanistan Rand Counterinsurgency Study Volume 4 (Santa Monica: National Defense Research Institute, 2008).

${ }^{5}$ Special Inspector General for Afghanistan Reconstruction (SIGAR), "Quarterly Report to the United States Congress," (Arlington: Special Inspector General for Afghanistan Reconstruction (SIGAR), 2015).

${ }^{6}$ United States Government Accountability Office, "Afghan Security: Lack of Systematic Tracking Raises Significant Accountability Concerns About Weapons Provided to Afghan National Security Forces," in Report to Congressional Committees, ed. United States Government Accountability Office (Washington, DC: United States Government Accountability Office, 2009), 24.

${ }^{7}$ Fred W. Baker, "Afghan Police Transform into Professional, Equipped Force," (Washington, DC: US Department of Defense, 2008).

${ }^{8}$ BBC, "Taliban Seize Afghan Police Base after Mass Surrender," BBC, no. Asia (2015); Maiwand Safi, "Uneasy Truce Holds in Afghan Valley," Institute for War and Peace Reporting (IWPR) (2011).

${ }^{9}$ The "legal framework for the Resolute Support Mission is provided by a Status of Forces Agreement (SOFA), signed in Kabul on 30 September 2014 and ratified by the Afghan Parliament on 27 November 2014". NATO/RS, "Resolute Support Mission (Rsm): Key Facts and Figures," (Brussels: Resolute Support Mission, North Atlantic Treaty Organization, 2015).

${ }^{10}$ North Atlantic Treaty Organization, "Afghan National Security Forces (Ansf)," in Media Backgrounder (Brussels: North Atlantic Treaty Organization, 2013).

${ }^{11}$ (SIGAR), "Quarterly Report to the United States Congress," 100.

${ }^{12}$ Edward Sagarin and Robert J. Kelly, "Political Deviance and the Assumption of Responsibility," Deviant Behavior 7, no. 3 (1986): 218.

${ }^{13}$ Dating back to the caliphate of Uthman, takfir was employed by the Kharijites as a means for circumventing established political order in response to perceived alleged unjust policies, nepotism, and greed among the leadership of the time. Irshaad Hussain, "The Hermeneutics of Takfir," (Islam from Inside, 2002).

${ }^{14}$ Matthew Rosenberg, "Drug Use, Poor Discipline Afflict Afghanistan's Army," Wall Street Journal, July 28, 20102010.

${ }^{15}$ Bill Roggio, "Afghan Policewoman Kills Us Military Adviser inside Interior Ministry," Long War Journal (2012).

${ }^{16}$ Antonio Giustozzi and Peter Quentin, "The Afghan National Army: Sustainability Challenges Beyond Financial Aspects," (Kabul, Afghanistan: Afghanistan Research and Evaluation Unit, 2014).

${ }^{17}$ UNAMA, "Annual Report on Protection of Civilians in Armed Conflict, 2009," (Kabul: United Nations Assistance Mission in Afghanistan, 2009).

${ }^{18}$ Scott Gates and Kaushik Roy, War and State-Building in Afghanistan : Historical and Modern Perspectives, Bloomsbury Studies in Military History, text.

${ }^{19}$ Thomas Ruttig, "Afghanistan between Democratization and Civil War: Post-2014 Scenarios," in Afghanistan, Pakistan and Strategic Change: Adjusting Western Regional Policy, ed. Joachim Krause and Charles King Mallory IV (New York: Routledge, 2014).

${ }^{20}$ NATO/RS, "Resolute Support Mission (Rsm): Key Facts and Figures." 
${ }^{21}$ The high ranking military official claimed that Sunni-Hanafi imam, Abo Hanifah and Shia-Jafari imam Jafar-e-Saddiq both decreed that praying toward Mecca is demonstration enough that one is not an apostate or kafir.

${ }^{22}$ The Holy Quran, 42:13.

${ }^{23}$ Mullah Mohammad Omar, 2011.

${ }^{24}$ Mohammad Omar, "Message of Felicitation of the Esteemed Amir-Ul-Momineen on the Occasion of the Eid-Ul-Odha," (2012).

${ }^{25}$ R. Hossain, "Afghanistan: Green-on-Blue Attacks in Context," (Washington, DC: Institute for the Study of War, 2012).

${ }^{26}$ William A. Byrd, "Who Will Pay for Afghan Security Forces?," Foreign Policy (2014).

27 "Revisiting Chicago: The Critical Need to Maintain Support for Afghanistan's National Security Forces Post-2014," (Washington, DC: United States Institute of Peace, 2014). 


\section{About the AISS}

The Afghan Institute for Strategic Studies (AISS) was established in October 2012 in Kabul. It aims to create an intellectual space for addressing strategic issues pertaining to Afghanistan in wider regional and international contexts. Promoting dialogue between and among different stakeholders is an end as well an integral means in attaining AISS' objectives. All activities and programs are based on the principles of professionalism, independence, internationalism and progressive values.

AISS is an independent research body, officially registered with the Afghan Ministry of Economy as a not-for-profit research institute dedicated to providing qualitative, non-partisan and policy-oriented research; publication, professional training and policy advocacy with a distinct focus on Afghanistan. Empowering and investing in Afghan youth constitutes the crosscutting priority of the AISS.

\section{Board of Advisors}

- Ambassador Kai Eide, former Special Representative to the UN Secretary General;

- Professor Radha Kumar, Director General, Delhi Policy Group (DPG);

- Mr. Nader Nadery, Director of Afghanistan Research and Evaluation Unit (AREU) and Head of the Free and Fair Election Foundation of Afghanistan (FEFA);

- Dr. Barnett Rubin, Director and Senior Fellow, Center on International Cooperation, and Professor of Political Science at New York University;

- Dr. Sima Samar, Chairwoman, Afghanistan Independent Human Rights Commission (AIHRC);

- Dr. Rangin Spanta, Former National Security, Government of Afghanistan;

- Professor Shahrbanou Tadjbakhsh, Chief Academic Advisor at the Afghan Institute for Strategic Studies (AISS), Director of the program on Human Security at the Master of Public Affairs (MPA), Institute of Political Studies, Sciences Po, Paris and Associate Researcher, Peace Research Institute Oslo (PRIO);

- Dr. David Samuel Sedney, Former Deputy Assistant Secretary of Defense for Afghanistan, Pakistan and Central Asia in the Office of the Assistant Secretary of Defense for Asian and Pacific Security Affairs; and

- Professor Wang Jisi, Dean, School of International Studies and Director of the Center for International and Strategic Studies, Peking University. 


\section{About the Authors}

Robert Zaman is a doctoral student with the Brussels School of International Studies where he is reading toward a PhD in International Conflict Analysis. He earned his BA in Economics from the University of Maryland at College Park, Maryland and an MA in International Relations from the University of Kent at Canterbury, United Kingdom. He also attended the China Foreign Affairs University in Beijing as a visiting scholar with its school of Diplomacy and International Relations. Robert has taught courses in security and development at Vesalius College and is a seminar tutor in methodology and the fundamentals of research at the Brussels School of International Studies. In addition to conceptualizing radicalization, his research interests include the role of traditional structures of authority and factors of influence on the dynamics of conflict and post-conflict state-building.

Lieutenant General Abdul Hadi Khalid is former Vice Minister for the Ministry of Interior (Mol). Prior to this role, General Khalid served as the Commanding Officer of the Afghan Special Counter-Narcotics Unit and as Security Deputy Minister. He attended the Afghan military academy in Kabul in 1977 and competed his MA in History and Military Pedagogy at the High Military College of Minsk in the Soviet Union between 1980 and 1985 . He is also a visiting lecturer at Dunya University and remains a senior security advisor to the Government of Afghanistan and private interests in country. General Khalid is fluent in Russian, Dari, Pashtu, and English. He is currently a research fellow at the Afghan Institute for Strategic Studies (AISS) in Kabul. 
This Page Intentionally Left Blank

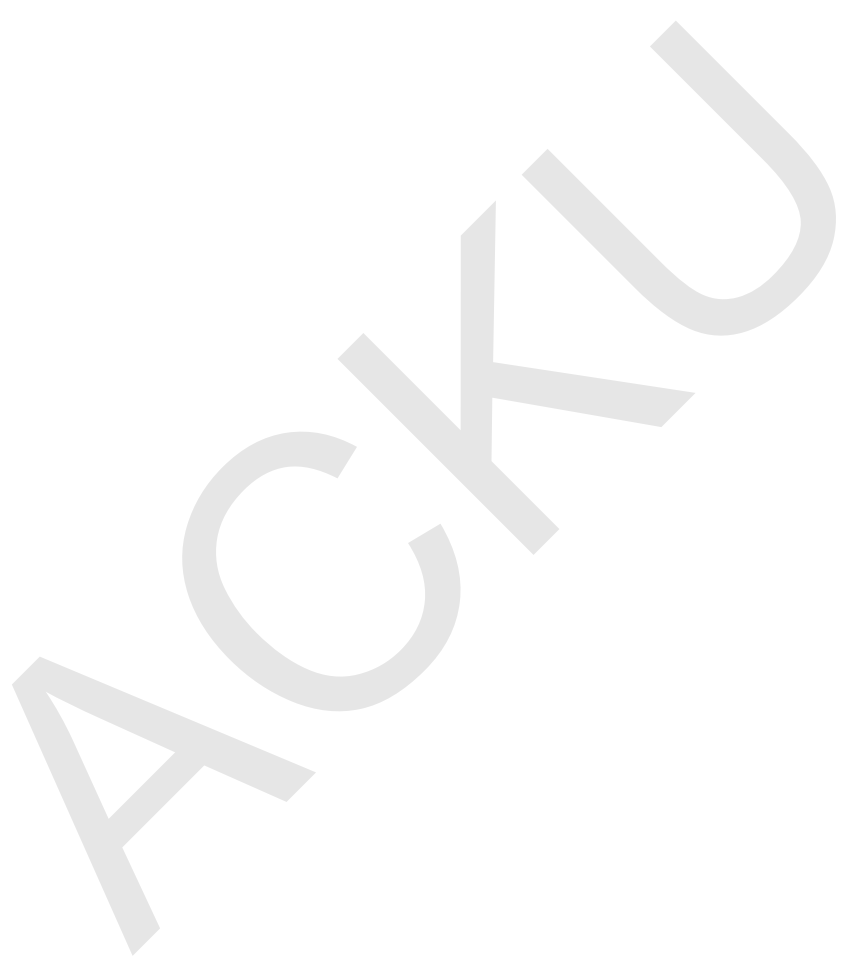




\section{CONTACT}

Afghan Institute for Strategic Studies (AISS)

Former Turquoise Mountain Fort I Post Box No: 5214 | Karte-Parwan I Kabul | Afghanistan

Robert Zaman

Senior Researcher, Department of Peace Studies

E: rz37@kent.ac.uk

Musab Omer

Researcher and Project Coordinator, Department of Peace Studies

E: musab.omer@aiss.af

www.aiss.af I contact@aiss.af I Facebook: facebook.com/afghaninstituteforstrategicstudies

Twitter: @aissofficialpag I Linkedln: Afghan Institute for Strategic Studies

Commercial use of all publications by the AISS is not permitted without the written consent of the AISS.

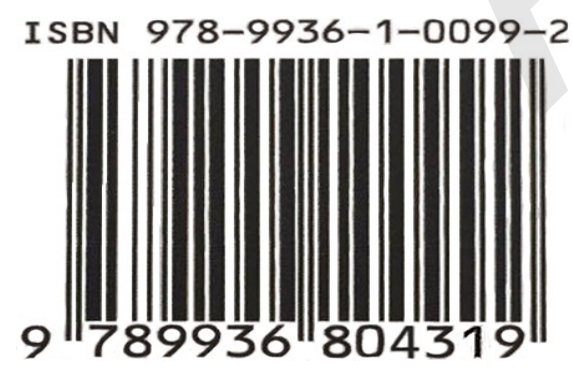

The analyses provided in this report are those of the research team and do not reflect the official position of Afghan Institute for Strategic Studies (AISS) or United States Institute of Peace (USIP). 